\title{
Baltica during the Ediacaran and Cambrian : A paleomagnetic study of Hailuoto sediments in Finland
}

Klein, $\mathrm{R}$.

2015-09

Klein , R , Salminen , J \& Mertanen , S 2015 , ' Baltica during the Ediacaran and Cambrian : A paleomagnetic study of Hailuoto sediments in Finland ', Precambrian Research, vol. 267 , pp. 94-105 . https://doi.org/10.1016/j.precamres.2015.06.005

http://hdl.handle.net/10138/329808

https://doi.org/10.1016/j.precamres.2015.06.005

cc_by_nc_nd

acceptedVersion

Downloaded from Helda, University of Helsinki institutional repository.

This is an electronic reprint of the original article.

This reprint may differ from the original in pagination and typographic detail.

Please cite the original version. 


\title{
Baltica during the Ediacaran and Cambrian: A paleomagnetic study of Hailuoto sediments in Finland
}

\author{
R. Klein ${ }^{\mathrm{a},{ }^{*}}$, J. Salminen ${ }^{\mathrm{a}, \mathrm{c}}$, S. Mertanen, \\ ${ }^{a}$ Division of Geophysics and Astronomy, Department of Physics, University of Helsinki, FI-00014, Helsinki, Finland \\ ${ }^{\mathrm{b}}$ Geological Survey of Finland, FI-02151, Espoo, Finland
}

${ }^{\mathrm{c}}$ Division of Geology, Department of Geosciences and Geography, University of Helsinki, FI-00014, Helsinki, Finland

* Corresponding author: robert.klein@helsinki.fi

\begin{abstract}
We present a new Late Neoproterozoic paleomagnetic pole for Baltica from an inclined $272 \mathrm{~m}$ deep oriented sedimentary drill core in Hailuoto, Western Finland. Three components of magnetization were isolated with alternating field (AF) and thermal demagnetization treatments. The ChRM (characteristic remanence magnetization) component is a high coercivity/unblocking temperature dual polarity component of $\mathrm{D}=334.4^{\circ} ; \mathrm{I}=57.7^{\circ}$ with $\alpha_{95}=5.8^{\circ}$ and $\mathrm{k}=25.2(\mathrm{~N}=26$ samples $)$, that passes a positive reversal test. This corresponds to a paleomagnetic pole of Plat $=60.5^{\circ} \mathrm{N}$, Plon $=$ $247.9^{\circ} \mathrm{E}$ with $\mathrm{A} 95=7.6^{\circ}$. As it is a dual-polarity ChRM with high coercivity/blocking temperature, with no resemblance to younger events, we interpret it as a primary component. A paleolatitude for Hailuoto of $38.3^{\circ}$ was calculated from the ChRM. Two secondary components were identified. The first is a low coercivity/blocking temperature component with a remanent magnetization of $\mathrm{D}=$ $239.0^{\circ} ; \mathrm{I}=67.3^{\circ} ; \alpha_{95}=8.7^{\circ}(\mathrm{N}=13$ samples $)$, which we interpret as drilling-induced remanent magnetization $(\mathrm{DIRM})$. The second secondary component has a remanent magnetization of $\mathrm{D}=$ $49.4^{\circ} ; \mathrm{I}=34.9^{\circ} ; \alpha_{95}=8.6^{\circ}(\mathrm{N}=5$ samples $)$ and is commonly seen in Fennoscandian formations.
\end{abstract}


The ChRM Hailuoto pole adds to the scattered Ediacaran paleomagnetic data of Baltica and indicate large distances between similar aged paleomagnetic poles. We present reconstructions of Baltica and Laurentia between 616 and $550 \mathrm{Ma}$ which move Baltica from high latitudes (615 Ma), over the polar region, to low latitudes (550 Ma), and Laurentia from low latitudes (615 Ma) to a polar position (570 $\mathrm{Ma})$ and back to an equatorial position $(550 \mathrm{Ma})$. Low to mid latitude position of Baltica determined by the Hailuoto paleomagnetic pole and the lack of glaciogenic sediments determined in an earlier study of Hailuoto sediments indicate a warm deposition environment.

Keywords: Ediacaran, Paleomagnetism, Paleogeography, Baltica, Laurentia, Hailuoto sediments

\section{Introduction}

The Late Neoproterozoic to Early Cambrian is a fascinating time interval in Earth's history. It includes global scale glaciations (Kirschvink, 1992; Hoffman et al., 1998; Hoffman and Schrag, 2002), the diversification of early life (Knoll, 1992), and the break-up of the supercontinent Rodinia (e.g. Hoffman, 1991; Dalziel, 1997; Bingen et al. 1998; Evans, 2009). Laurentia and Baltica occupied central positions at the core of Rodinia. They became more isolated from other continents as rifting along Rodinia's margins occurred during the mid to late Neoproterozoic. By the start of the Ediacaran (ca. $635 \mathrm{Ma}$ ) the break-up of Rodinia was near completion. With the exception of Baltica and Siberia, all continents were separated from Laurentia (Li et al., 2013). Li et al. (2013) further show that by ca. $580 \mathrm{Ma}$ the break-up of Rodinia was complete, Gondwana was in its early stages of assembly, and Baltica and Siberia had separated from Laurentia.

The role of paleomagnetism in reconstructing lithospheric blocks in their ancient paleopositions is vital. Paleomagnetism is the only quantitative tool for providing ancient latitudes and azimuthal 
orientations of continents and it also reveals information of the geomagnetic field in the past. A reliable paleomagnetic pole generally fulfills at least three of the seven quality criteria of Van der Voo (1990). If two of these include adequate geochronology and a positive paleomagnetic field test, the obtained paleomagnetic pole can be called a "key" pole (Buchan et al., 2000; Buchan, 2013). The paleogeography for the Ediacaran-Cambrian is the subject of significant controversy and it has puzzled researchers for the past two decades (Meert et al., 1993, 1994; Kirschvink et al., 1997; Evans, 1998; Meert, 1999; Popov et al., 2002; Meert et al., 2003; Nawrocki et al., 2004; Iglesia Llanos et al., 2005; McCausland et al., 2007; Meert et al., 2007; Pisarevsky et al., 2008; Abrajevitch and Van der Voo, 2010; McCausland et al., 2011). Ediacaran paleomagnetic data is complex since contradictory paleomagnetic results from coeval rocks have been obtained from both Baltica and Laurentia. McCausland et al. (2011) show how Laurentia has unclear paleogeographic relations during the Precambrian-Cambrian transition. Published paleomagnetic results from the Ediacaran period positions Laurentia at low paleolatitudes at $615 \mathrm{Ma}$, shortly after that at high southern latitudes during 590-570 Ma, and then again at low latitudes from 565 to $550 \mathrm{Ma}$.

A similar phenomenon is observed in high quality paleomagnetic data from Baltica. Higher quality paleomagnetic data for Baltica exist for only three time intervals during the Ediacaran-Ordovician (Meert, 2014). The 616 \pm 3 Ma pole from Egersund dykes (Walderhaug et al., 2007) positions Baltica at high latitudes. Between $570 \mathrm{Ma}$ and $550 \mathrm{Ma}$, poles from Zigan formation $(547.6 \pm 3.8 \mathrm{Ma}$; Levashova et al., 2013), Verkhotina sediments (550.2 $\pm 4.6 \mathrm{Ma} ; 550 \pm 5.3 \mathrm{Ma}$; Popov et al., 2005), Winter coast sediments (555 $\pm 3 \mathrm{Ma}$; Popov et al., 2002), Zolotitca sediments (550.2 $\pm 4.6 \mathrm{Ma}, 550$ $\pm 5.3 \mathrm{Ma}$; Iglesia Llanos et al., 2005), Chernokamenskay group sediments (557 $\pm 13 \mathrm{Ma}$, Fedorova et al., 2014), Basu-Kukkarauk formation (ca. 560 Ma, Golovanova et al., 2011), and recent poles from 560-570 Ma Kurgashlya, Bakeevo and Krivava Luka ormations (Lubnina et al., 2014) positions Baltica at low to equatorial latitudes. The Late Cambrian - Middle Ordovician poles from Narva Limestones (Khramov and Iosifidi, 2009) and St. Petersburg Limestones (Smethurst et al., 1998) 
positions Baltica at high latitudes again. Based on these high quality data Baltica swayed by ca. $90^{\circ}$, from high latitudes at $616 \mathrm{Ma}$ to low latitudes at 570 - $550 \mathrm{Ma}$ and again to high latitudes from 550 to $500 \mathrm{Ma}$. The other Late Neoproterozoic poles presented in Table 2 are too questionable or unreliable to include in the APWP. The two poles - equatorial and high latitude - from $584 \pm 7 \mathrm{Ma}$ $\left({ }^{39} \mathrm{Ar}-{ }^{40} \mathrm{Ar}\right)$ Alnö carbonatite complex dikes were artificially derived from a wide spread in magnetic declinations and inclinations (Meert et al., 2007). The $583 \pm 15 \mathrm{Ma}\left({ }^{39} \mathrm{Ar}-{ }^{40} \mathrm{Ar}\right)$ pole from Fen Carbonatite Complex, lack stability tests and is likely a Permo-Triassic overprint (Meert, 2014). The Cambrian Andarum-alum limestone and Tornetrask group poles are questionable. The Tornetrask results (Torsvik and Rehnström, 2001) come from samples taken close to tectonically disturbed regions of Caledonian front, which can cause complications in interpreting those results (Meert, 2014). Pole for Andarum-alum is calculated only from 11 samples yielding thus only virtual geomagnetic pole, which cannot be used in APWP. Both the Tornetrask and Andarum-alum (Torsvik and Rehnström, 2001) have a dual-polarity magnetization, but they fall close to the remagnetized Fen Complex pole.

Explanations for the two almost coeval magnetization components (high and low latitude) include fast continental motions (Meert and Tamrat, 2004), rapid true polar wander (TPW) (Mitchell et al., 2011), or a non-actualistic geodynamo where the geomagnetic field alternated between axial and equatorial configurations during the Ediacaran (Abrajevitch and Van der Voo, 2010). Abrajevitch and Van der Voo (2010) argued that high plate velocities and true polar wander are implausible explanations for such rapid changes in the positions of continents, as both TPW and plate tectonics are speed-limited phenomena. However, as Meert (2014) pointed out, the analysis of Abrajevitch and Van der Voo (2010) analysis relied on problematic poles for Baltica, implying apparent polar wander (APW) rates exceeding $70 \mathrm{~cm} / \mathrm{yr}$ (Meert, 2007). By taking into account reliable poles only, rapid plate motions can explain individual segments of the apparent polar wander path (APWP). 
The Neoproterozoic is also characterized by global scale glaciations. Two major glaciation events occurred during the Ediacaran, namely the Marinoan (ca.635 Ma) and the Gaskiers (ca. $580 \mathrm{Ma}$ ) (e.g. Hoffman and Li, 2009). The Marinoan glaciation extended from $>70^{\circ}$ palaeolatitude to the equator (e.g. Hoffman and Li, 2009), implying global glaciation and has been interpreted to represent a Snowball Earth event (Kirschvink, 1992; Hoffman et al., 1998; Hoffman and Schrag, 2002). Marinoan glacial deposits have been found on all major continental blocks except for the North China block (Li et al., 2013). Gaskiers glacial deposits are found on Baltica, Laurentia, North China, Australia, Tarim, Avalonia, Congo-São Francisco and Amazonia (Li et al., 2013), however, feeble evidence of low latitude glaciation (e.g. Hoffman and Li, 2009) suggests that the Gaskiers was not as widespread as the Marinoan. Li et al. (2013) point out that on the Avalon Peninsula, Newfoundland, precise TIMS $\mathrm{U}-\mathrm{Pb}$ zircon dates appear to constrain the duration of the Gaskiers glaciation to $\leq 2.6$ m.y. (Condon and Bowring, 2011). The short duration has commonly been regarded as evidence that it was not a Snowball glaciation (e.g., Halverson, 2006).

The aim of the present work is: 1) to obtain a new paleomagnetic pole for Baltica; 2) to test the Late Neoprpterozoic paleogeoraphic positions of Baltica; and 3) to better understand the environmental conditions during that time. With a new Late Neoproterozoic pole, we further aim to explore if the large sways in the Ediacaran APWP can be explained by high plate velocities alone.

\section{Geological background}

The assembly of the Baltica began at 2.0 Ga when Sarmatia and Volgo-Uralia joined each other to form the Volgo-Sarmatian protocraton, which existed as a separate unit until ca. 1.8-1.7 Ga when it docked with Fennoscandia and a unified Baltica was created (Bogdanova et al., 2008). After the movements of the Svecofennian orogeny terminated at ca. $1750 \mathrm{Ma}$ (Bogdanova et al., 2008) and Baltica and Laurentia formed a joint NENA continent (Gower et al., 1990). This was followed by a geologically passive time of about $150 \mathrm{Ma}$ when no significant deformation occurred and when the 
crust eroded to a peneplain. The quiet time ended with the intrusion of rapakivi granites and associated bimodal magmas at 1650 - 1500 Ma (Rämö and Haapala, 2005; Bogdanova et al., 2008). This caused instability of the crust and led to the development of intracratonic rift basins between ca. $1600-1300$ Ma when thick fluvial layers started to fill the basins (Kohonen and Rämö, 2005). The crust was thinned by about $20 \mathrm{~km}$ at the Gulf of Finland and about $10 \mathrm{~km}$ at Lake Ladoga in Russia and at the Bay of Bothnia (Figure 1; Korja et al., 1993).

Due to the Sveconorwegian orogeny, the southwestern parts of the Fennoscandian shield were uplifted. This resulted in the formation of thick and hundreds of kilometers long foreland sedimentary deposits east of the Svoconorwegian orogeny (Larson et al., 1999). During Neoproterozoic a vast area of the crystalline bedrock was exposed when about 500-2000 meters of sediments were eroded away (Puura et al., 1996). Due to marine transgression, a new sedimentary event began in Baltica at the end of the Neoproterozoic (Puura et al., 1996). Fluvial and shallow marine deposition prevailed in the slowly submerging northwestern part of Baltica (Kohonen and Rämö, 2005). These sedimentary layers covered the entire southern Finland (Puura et al., 1996; Bogdanova et al., 2008). Today, the scattered Meso- and Neoproterozoic deposits of sedimentary rocks in Finland are preserved from erosion in tectonic basins in Satakunta, Muhos, the Gulf of Bothnia (the northern arm of the Baltic Sea) as well as in meteorite impact craters (Kohonen and Rämö, 2005).

The Muhos sedimentary basin forms a SE-NW trending area of about $20 \mathrm{~km}$ by $50 \mathrm{~km}$, mainly consisting of Mesoproterozoic clay and silt rocks (Kohonen and Rämö, 2005). This graben-like formation has a maximum depth of about $1 \mathrm{~km}$ (Kalla, 1960) and is surrounded by the late orogenic (ca. $1800 \mathrm{Ma}$ ) granitoid complex. The Muhos formation has been considered to be of the same age as the Mesoproterozoic Satakunta sandstone (Bogdanova et al., 2008). The Muhos sedimentary formation continues to the West and covers almost the entire Bothnian Bay between Finland and Sweden (Wannäs, 1989). The Neoproterozoic Hailuoto formation was deposited on top of the Muhos formation and occurs West of the Muhos on the island of Hailuoto. Hailuoto Island is situated off the 
coast of the city of Oulu, Northern Finland $\left(65^{\circ} \mathrm{N} 25^{\circ} \mathrm{E}\right)$ (Fig. 1). The island arose from the Bothnian Bay during the Quaternary post-glacial land uplift (Tynni and Donner, 1980). The sedimentary bedrock of Hailuoto is covered by a Quaternary layer of loose sand of up to $c a .70 \mathrm{~m}$ thick. The bedrock consists of interbedded conglomerate, sandstone and mudstone up to a maximum depth of ca. $560 \mathrm{~m}$. The dominant rock type of the Hailuoto formation is a medium-grained, pale pink or light greenish subarkose (Veltheim, 1969; Tynni and Donner, 1980).

\section{INSERT FIGURE 1 HERE}

Tynni and Donner (1980) point out that the sedimentary rocks of Hailuoto resemble glacial clay, but are in fact not glaciogenic. The depositional age of the Hailuoto sediments is poorly constrained. The micro-fossils, such as filamentous blue-green algae (eg. Oscillatoriopsis magna), in the upper part of the formation (Tynni and Donner, 1980) indicates a late Neoproterozoic age. The micro-fossils diversity also indicates a deposition environment of low oxygen content and warm temperatures. Tynni and Donner (1980) correlated the upper part of the Hailuoto sequence with the upper part of the Visingö formation in Sweden. Subsequent dating of shales and clay from the the upper part of the Visingö formation gave a Rb/Sr age of 663 - $703 \mathrm{Ma}$ (Bonhomme and Welin, 1983). Yet the fossil species suggest younger ages for Hailuoto, since among the Acritarch fossils found in Hailuoto sediments are species Kildinella sinica and Churia cicularis (Tynni and Donner, 1980). Both are closely related to the genus Leiospaeridia (Lindgren, 1981, Tynni and Donner, 1980) found in the Kotlin formation of the Vendian sediments in Estonia (Mens and Pirrus, 1997). The age of the lower Kotlin boundary in the White Sea area has been confined between $551 \mathrm{Ma}$ and $548 \mathrm{Ma}$ based on U$\mathrm{Pb}$ zircon dates of volcanic tuffs (Grazhdankin et al., 2011). So far the Hailuoto depositional age remains poorly constrained as Late Neoproterozoic, if the correlation with Visingö is correct then age of deposits is older than 663 - $703 \mathrm{Ma}$, but based on obtained old fossil record the sediments might be as young as the Precambrian-Cambrian boundary. Although the exact age of deposition of the 
Hailuoto sediments is not known, in this paper we will assume an age range of 570-600 Ma suggested by Tynni and Donner (1980).

\section{Methods}

\subsection{Sampling and sample preparation}

The 272 m deep Hailuoto drill core M52-HAIL-04-005 mainly consists of conglomeratic sandstone and sandy conglomerates with smaller layers of mudstone, and sandstone (Solismaa, 2008; Fig. 4). The conglomeratic sediments are poorly sorted, and the granule and small pebble sized clasts are sparsely dispersed in a finer grained matrix. The drilling was done with an angle of $70^{\circ}$ to the direction of $226^{\circ}$. In the core layers inclined to the borehole axis can be seen. Orientation was done by using the Ballmark orientation system, in which an indent marking is made on the drill core at the time the core is broken. This is one of the first times when paleomagnetic data is obtained of the rocks from inclined deep drill core, which use simple geometry for sample orientation instead of cumbersome and imprecise in-door studies for the same purpose.

Oriented samples of sedimentary rock were prepared from the drill core. Samples with a maximum length of about $6 \mathrm{~cm}$ were first cut from the drill core and from these $7-8 \mathrm{~cm}^{3}$ cubic specimens parallel to the core, were prepared for paleomagnetic measurements. The sample numbering corresponds with the depth of the sample in the drill core (in decimeter), and in many cases more than one specimen were prepared from a sample. Samples from the entire sedimentary part of the drill core were measured (Fig. 4). There are three large gaps of more than $10 \mathrm{~m}$ each between measured samples at depth ranges 69.5 - $79.7 \mathrm{~m}, 87.2$ - $101.2 \mathrm{~m}$ (largely lost core), and 170.2 - $181.8 \mathrm{~m}$ (conglomeratic with clasts up to $5 \mathrm{~cm}$ ). When we exclude these gaps the average distance between measured samples is 1.6 metres, with distances as small as $10 \mathrm{~cm}$ (Fig. 4). 


\subsection{Laboratory measurements}

The measurements were carried out at the Geophysics laboratory of the Geological Survey of Finland (GTK) and the Solid Earth Geophysics Laboratory of the University of Helsinki (UH). Paleomagnetic measurements with progressive alternating field (AF) and thermal demagnetizations were performed using a 2G-DC SQUID magnetometer (UH), 2G-RF SQUID magnetometer (GTK) (both equipped with Model 2G600 automatic sample degaussing systems) and an ASC Scientific TD-48SC (UH) thermal demagnetizer using an argon atmosphere to minimize oxidation during thermal demagnetization. Prior to demagnetizing part of the samples were immersed in liquid nitrogen in a non-magnetic field (Borradaile, 2004) and after that they were heated up to $125^{\circ} \mathrm{C}$ to demagnetize remanent magnetization carried by goetithe. Magnetic susceptibility was measured after each heating step to monitor possible chemical alterations.

Natural remanent magnetization (NRM) components were visually identified using stereographic and orthogonal projections (Zijderveld, 1967) and the directions were calculated by a least squares method (Leino, 1991), with a mean angular deviation (MAD) equal or less than $6^{\circ}$ (with a few coarser grained samples a higher MAD was accepted). Mean remanence directions for the different components were calculated according to Fisher (1953). APWP and paleogeographic reconstructions were plotted with the GMAP programme (Torsvik and Smethurst, 1999). The magnetic carriers were identified by thermomagnetic analysis of selected specimens along the depth profile, using Agico's KLY-3S Kappabridge system (UH), which measures the bulk susceptibility (k) of the samples while heating the samples from room temperature to $700{ }^{\circ} \mathrm{C}$ and cooling back to room temperature (in Argon gas).

\section{Results}

\subsection{Paleomagnetic and rock magnetic results of Hailuoto}


A total of 148 specimens from 90 samples were measured, of which 48 specimens from 36 samples gave stable results. Results from rest of 90 samples were unstable and will not be further discussed. From accepted 36 samples we identified three prevailing paleomagnetic components, which are summarized in Table 1 and examples of thermal demagnetization behaviour are shown in Fig. 2.The mean paleomagnetic directions are plotted in Fig. 3. As shown in Table 1 and Fig. 4, the results were obtained from various lithologies along the drill core, however the coarser-grained parts of the drill core yielded largely unstable magnetizations, and were therefore unusable. It must be noted that the stratigraphic $\log$ in Fig. 4 is simplified from a detailed stratigraphic log by Solismaa (2008), and that the indicated lithologies are interbedded with many layers that are too small to be detected on the scale of the figure.

\section{INSERT TABLE 1 HERE}

\section{INSERT FIGURE 2 HERE}

We employed the standard convention of assigning "normal" polarity to north-directed ChRM vectors from Proterozoic rocks in Baltica; relating this arbitrary definition to the absolute sense of Precambrian geomagnetic polarity is uncertain due to the lack of continuity in the Baltica APWP prior to Phanerozoic. The dual polarity ChRM componentwas obtained from 26 samples. Normal polarity component shows an intermediate downward NNW direction (7 samples) and reversed polarity component shows an intermediate upward SSE direction (19 samples). Based on thermal demagnetization curves, the magnetic carriers of the ChRM are magnetite and hematite. Presence of both magnetite and hematite is supported by the thermomagnetic curves (susceptibility vs. temperature) of samples at $79.9 \mathrm{~m}$ and $170.2 \mathrm{~m}$ depths respectively (Fig. 5). As can be seen in Figure 2a the reversed polarity ChRM is carried by both magnetite and hematite. This indicates that hematite is produced soon after deposition and the chemical remanent magnetization in hematite has recorded the magnetic field direction essentially contemporaneous with magnetite and is regarded as a primary 
magnetization. The case is slightly different for normal polarity samples, where two almost similar directed components were obtained (Fig. $2 b)$. The normal $\left(\mathrm{D}=323.5^{\circ} ; \mathrm{I}=40.7^{\circ} ; \alpha_{95}=14.5^{\circ} ; \mathrm{k}=18.8\right.$, $\mathrm{n}=7)$ and reversed $\left(\mathrm{D}=158.5^{\circ} ; \mathrm{I}=-45.5^{\circ} ; \alpha_{95}=8.5^{\circ} ; \mathrm{k}=16.5, \mathrm{n}=19\right)$ observed $\mathrm{ChRM}$ directions pass the McFadden and McElhinny (1990) reversal test with classification C (observed angle, $\gamma=$ $11.93^{\circ}$ and, critical angle, $\gamma_{\mathrm{c}}=18.17^{\circ}$ ). To confirm primary remanence of ChRM, a conglomerate test was attempted on $0.5-2 \mathrm{~cm}$ clasts, prepared from conglomeratic samples. Although the remanence of the clasts show a random distribution, they proved to have unstable magnetizations, and the conglomerate test is therefore unreliable.

The other two magnetization components obtained from Hailuoto samples are overprinted magnetization components. The first one with low coercivities/blocking temperatures (Fig.2) is carried by 13 of the measured samples. It is directed to the SW and has a steep positive inclination similar to the drilling direction. We interpret it as a drilling-induced remanent magnetization (DIRM), which is a common phenomenon in multi-domain magnetic grains in sedimentary rocks (Audunsson and Levi, 1989; De Wall and Worm, 2001). It has no geological meaning and will not be further discussed. The present earth field (PEF) direction for Hailuoto is $\mathrm{D}_{\mathrm{PEF}}=8.2^{\circ}$; $\mathrm{I}_{\mathrm{PEF}}=75.9^{\circ}$ (Fig. 4.) and was not detected in any of the measured samples, as it was possibly overprinted by the DIRM. The second secondary magnetization component was obtained from five samples and is directed to the NE with a moderately steep positive inclination. It is isolated from low to intermediate coercivities and temperatures. This component often occurs in Fennoscandian formations, and it was recently obtained from Subjotnian Satakunta and Åland diabase dykes (Salminen et al., 2014, Salminen et al., 2015). It is considered to represent a late Paleozoic secondary magnetization event (Preeden et al. 2009). 


\section{INSERT FIGURE 3 HERE}

\section{INSERT FIGURE 4 HERE}

\section{INSERT FIGURE 5 HERE}

\subsection{Inclination shallowing}

It is important to make inclination corrections for paleomagnetic results obtained from sedimentary rocks since inclination shallowing can be as much as $20^{\circ}$ at mid-latitudes (Kodama, 2012). Examples of sedimentary inclination shallowing are numerous in a variety of natural settings (e.g. Bilardello and Kodama, 2010) and by several laboratory re-deposition experiments (e.g. Tauxe and Kent, 1984). As Domeier et al. (2012) point out due to the great diversity of sediment characteristics and depositional conditions, in addition to the assortment of specific mechanisms by which a magnetization may acquire a shallow inclination bias, the magnitude of the bias in sedimentary rocks is variable. So far there are four ways to correct this: 1) the DRM tensor approach of Jackson et al. (1991); 2) the Elongation/Inclination (E/I) method of Tauxe and Kent (1984) using the statistical field model TK03.GAD; 3) the E/I method of Tauxe and Kent (2004) using samples from a single horizon and assuming a Fisher (1953) distribution; and 4) a blanket correction based on assumed values for flattening factor $\mathrm{f}$ using an inclination correction equation by King (1955):

$\tan \left(\mathrm{I}_{\mathrm{o}}\right)=\mathrm{f} \tan \left(\mathrm{I}_{\mathrm{f}}\right)$

where $\mathrm{I}_{\mathrm{o}}$ is the observed inclination, $\mathrm{I}_{\mathrm{f}}$ is the field inclination and $\mathrm{f}$ is an empirically derived 'flattening factor' (Tauxe et al., 2008). According to the compilation of Bilardello and Kodama (2010), f values from magnetite dominated sedimentary rocks range from 0.54 to 0.79 , with a mean of 0.65 , whereas hematite-dominated sedimentary rocks have yielded f values from 0.4 to 0.83 , with a mean of 0.59 . We corrected the ChRM using the flattening estimate since the DRM tensor is difficult to quantify; the first E/I method requires a large data set $(>100)$, which we do not have; the second E/I method has never been tried in practice. We followed the suggestion made by Domeier et al. (2012) and 
Torsvik et al. (2012) and used a flattening estimate of $\mathrm{f}=0.6$. The results are shown in Table 1 and Fig. 3 together with the observed results. The normal $\left(\mathrm{D}=323.1^{\circ} ; \mathrm{I}=54.2^{\circ} ; \alpha_{95}=12.0^{\circ} ; \mathrm{k}=26.3, \mathrm{n}=\right.$ 7) and reversed $\left(\mathrm{D}=158.5^{\circ} ; \mathrm{I}=-58.7^{\circ} ; \alpha_{95}=6.7^{\circ} ; \mathrm{k}=26.1, \mathrm{n}=19\right)$ inclination corrected ChRM directions also pass the reversal test with classification $C$ (observed angle, $\gamma=9.84^{\circ}$ and, critical angle, $\gamma_{c}=16.46^{\circ}$ ). Moreover the statistics of bot normal and reversed directions get better after the inclination correction.

\section{Discussion}

\subsection{The Hailuoto palemagnetic pole}

The combined observed ChRM component of the Hailuoto sediments $\left(\mathrm{D}=334.2^{\circ} ; \mathrm{I}=44.4^{\circ} ; \alpha_{95}=\right.$ $7.2^{\circ} ; \mathrm{k}=16.5$ ) yields a paleomagnetic pole of Plat $=48.7^{\circ} \mathrm{N}$ and Plon $=241.1^{\circ} \mathrm{E}$ with $\mathrm{A} 95=8.1^{\circ}$.

The inclination corrected direction of $\mathrm{D}=334.4^{\circ} ; \mathrm{I}=57.7^{\circ} ; \alpha_{95}=5.8^{\circ} ; \mathrm{k}=25.2$ yields a paleomagnetic pole of Plat $=60.5 \mathrm{~N}^{\circ}$ and $\mathrm{Plon}=247.9 \mathrm{E}^{\circ}$ with $\mathrm{A} 95=7.6^{\circ}$. As it is a dual-polarity ChRM with high coercivity/blocking temperature, with no resemblance to younger events, we interpret it as a primary component. Furthermore, the confidence limit $\left(\alpha_{95}\right)$ of the ChRM improves after the inclination correction, suggesting that it is the primary DRM. The paleolatitude of Hailuoto implied by the inclination corrected $\mathrm{ChRM}$ is $38.3^{\circ}$.

The Hailuoto paleomagnetic pole passes five of the seven Van der Voo reliability criteria (Van der Voo, 1990) for paleomagnetic data: a sufficient number of samples, adequate demagnetization (including vector subtraction), structural control and tectonic coherence with Baltica, the presence of reversals, and no resemblance to younger (i.e. Phanerozoic) paleopoles (Torsvik et al. 2012). It lacks the critical first and fourth criteria, i.e. a well determined age and a field stability tests, and can therefore not be regarded a key paleomagnetic pole (Buchan, 2013). Moreover the Hailuoto depositional age remains poorly constrained as Late Neoproterozoic (above in section 2). Although 
the exact age of deposition of the Hailuoto sediments is not known, in this paper we will assume an age range of 570-600 Ma suggested by Tynni and Donner (1980), which is also supported by the fact that the inclination corrected Hailuoto pole plots close to the well defined 560-570 Ma pole from Krivaya Luka formation (Lubnina et al., 2014).We wish to include the Hailuoto paleomagnetic pole in the discussion of the Ediacaran APWP and reconstructions due to its crucial age range.

\subsection{Ediacaran apparent polar wander path for Baltica}

We plotted the ChRM pole of Hailuoto with selected Neoproterozoic - Cambrian poles, listed in Table 2 (Fig. 6.). Although the exact deposition age of the Hailuoto sediments is unsure, for the purpose of this discussion we assume the age range proposed by Tynni and Donner (1980) of 600 $570 \mathrm{Ma}$, which places the age of the Hailuoto pole between the Egersund (616 Ma) and the Verkhotina (Popov et al. 2005) and Zolotitca (Iglesia Llanos et al. 2005) poles (ca. $550 \mathrm{Ma}$ ). The polarity was chosen to minimize the distances between the older Egersund pole (616 Ma) and younger poles (570$560 \mathrm{Ma}$ ) from Southern Urals. In Table 2 Ediacaran poles are classified into highly reliable A grade poles (well determined age and positive field stability test), seemingly reliable B grade poles (well determined age or positive field test), and questionable to unreliable C and D grade poles (neither well determined age nor positive field test). Considering the Hailuoto pole together with A and B grade poles, we propose a loop in the APWP that starts at the Egersund pole (616 Ma), jumps to the Hailuoto pole (ca. 600 - $570 \mathrm{Ma}$ ), and follows the poles of Krivaya, Kurgahlya and Bakeevo formations (570 - $560 \mathrm{Ma}$ ) (Lubnina et al. 2014), continues to the $550 \mathrm{Ma}$ Verkhotina (Popov et al. 2005) and Zolotitca (Iglesia Llanos et al. 2005) poles, and ends at the St. Petersburg limestone pole (Smethurst et al. 1998) close to the Egersund pole (illustrated with black dotted line in Fig. 6A). The Ediacaran poles of Laurentia (Fig.6B) starts with the Long Range dykes pole (615 Ma) (Murthy et al. 1992) followed by the poles of Baie de Moutons A (583 Ma) (McCausland et al. 2011), Callandar 
alkaline complex (Symons and Chiasson, 1991) and Catoctin basalts (575 Ma) (Meert et al. 1994), and Skinner cove (550 Ma) (McCausland and Hodych, 1998), and completing the loop with the Florida Mountains auriole pole (503 Ma).

The angle of the Baltica APWP segment between the Egersund dyke pole (616 Ma) and the Hailuoto pole is $98^{\circ}$ for the uncorrected pole and $86^{\circ}$ for the inclination corrected pole $(\mathrm{f}=0.6)$, which infers a plate motion of between $c a .24$ and $21 \mathrm{~cm} / \mathrm{yr}$ respectively with the lower Hailuoto age limit of 570 Ma. This is consistent with the upper speed limit for plate tectonics (between 20 and $25 \mathrm{~cm} / \mathrm{yr}$ ) reported by Meert et al., (1993) and Gurnis \& Torsvik (1994). The APWP of Baltica between the 550 Ma mean pole and the St Peterburg (478 Ma) (Smethurst et al. 1998) pole (Fig. 6A) yields an $87^{\circ}$ angle which results in a velocity of $c a .16 \mathrm{~cm} / \mathrm{yr}$ when considering only $\mathrm{A}$ and $\mathrm{B}$ grade poles.

\section{INSERT TABLE 2 HERE}

\section{INSERT FIGURE 6 HERE}

\subsection{True polar wander and a non-actualistic geogynamo during the Ediacaran}

The APWP of Baltica presented in Fig. 6 is plausible as a result of high plate velocity alone, however this does not negate the TPW (Mitchell et al., 2011) and non-actualistic geodynamo (Abrajevitch and Van der Voo, 2010) hypotheses for the large sway in the APWP, especially if we consider the higher age limit of $600 \mathrm{Ma}$ for the Hailuoto formation.

True polar wander (TPW) (Evans, 2003; Mitchell et al., 2011) and a non-actualistic geodynamo (Abrajevich and Van der Voo, 2010) are two hypotheses given as possible mechanisms for the rapid continental motion during the Ediacaran. True polar wander is the rotation of the Earth with respect to its spin axis causing the geographic locations of the North and South poles to change or "wander". Such a shift in poles results in a systematic change in the APWP's of all cratons. Although the APWP's for Baltica and Laurentia presented in Fig. 6 both form a loop starting at ca. 615 Ma and 
ending at ca. $500 \mathrm{Ma}$, the angles between individual coeval poles differ, and therefore negate TPW as a main cause for large APWP segments.

In the case of Laurentia, the large angle of $66^{\circ}$ of the APWP segment between Catoctin Basalts (572 $\mathrm{Ma}$ ) and Sept-Iles intrusions (564 Ma), which equates to $1.05 \mathrm{~m} / \mathrm{yr}$, cannot be explained by high plate velocity alone. However, the non-actualistic geodynamo hypothesis by Abrajevitch and Van der Voo (2010), which postulates an alternation of the geomagnetic dipole axis between a co-axial and an equatorial alignment, partly relies on problematic poles for both Laurentia and Baltica. The Grenville dykes yield both a shallow and steep pole, however only the steep pole can be considered a primary pole as it is supported by a positive field test (Murthy 1971, Halls, et. al. 2015). In the case of Baltica the model is based on the Alnö carbonate complex (584 $\pm 7 \mathrm{Ma}$ ) (Meert et al. 2007, Piper 1981) in which both a high and a low latitude component co-exist in the same unit. However the primary nature has not been proven for either. Furthermore, the Fen carbonate complex pole (Meert et al. 1998), another pole in the model, lacks stability tests and is likely a Permo-Triassic overprint (Meert 2014). When we omit these problematic poles the model resembles the APWP presented here, i.e. a back and forth sway from shallow to steep back to shallow poles.

\subsection{Reconstruction of Baltica and Laurentia between $615 \mathrm{Ma}$ and $550 \mathrm{Ma}$}

The reconstructions illustrated in Fig. 7 show a possible scenario for Baltica and Laurentia between $615 \mathrm{Ma}$ and $550 \mathrm{Ma}$. In the Baltica reconstructions we consider an age of 600-570 Ma for Hailuoto, but as mentioned above, the Hailuoto sedimentary formation may extend this age rage. The poles used for the reconstructions are listed in Table 3. In these reconstructions Baltica moves from a high latitude position at $615 \mathrm{Ma}$ to low and mid latitudes between $600 \mathrm{Ma}$ and $550 \mathrm{Ma}$. The orientation of Baltica is very similar between $600 \mathrm{Ma}$ and $550 \mathrm{Ma}$ with the west coast of Norway directed towards the pole. In the 615 Ma reconstruction however, the west coast of Norway points away from the pole, implying that Baltica moved across the polar region between $615 \mathrm{Ma}$ and $600 \mathrm{Ma}$ without significant 
rotation. This motion of Baltica coincides with the final break-up of Baltica and Laurentia from Rodinia configuration and the opening of the Iapetus Ocean, which is supported by the fact the Long Range (Laurentia) and Egersund (Baltica) dykes are rift-related (Bingen et al. 1998, Puffer 2002). Laurentia moved from low latitudes at $615 \mathrm{Ma}$ to a polar position at ca. $570 \mathrm{Ma}$ and back to an equatorial position at $550 \mathrm{Ma}$ (Fig 7). The reconstructions presented here are consistent with recent reconstructions by Meert (2014), Li et al. (2013) and McCausland (2011).

\section{INSERT FIGURE 7 HERE}

\section{INSERT TABLE 3 HERE}

The polar position of Laurentia at $570 \mathrm{Ma}$ (Fig 7) and the high latitude model of early Gondwana land at $575 \mathrm{Ma}$ (Pisarevsky et al. 2008), as well as the low latitude of Baltica presented in this study and warm deposition environment of Hailuoto sediments (Tynni and Donner, 1980), suggest that no global scale glaciation event, as presented in the snowball (Kirschvink, 1992) model, took place during the time of the Hailuoto deposition. These conditions therefore indicate zonal surface temperature gradients similar to today, i.e. warm equatorial areas and cold polar areas, unlike the high obliquity model presented by Williams $(1975,1993,2008)$.

\section{Conclusion}

We present a new Neoproterozoic pole for Baltica obtained from a drill core from Hailuoto sedimentary rock with an estimated age of $570-600 \mathrm{Ma}$. The paleomagnetic pole Plat $=48.7^{\circ} \mathrm{N}$, Plon $=241.1^{\circ} \mathrm{E}, \mathrm{A} 95=8.1^{\circ}$ (inclination corrected: Plat $=60.5^{\circ} \mathrm{N}$, Plon $=247.9^{\circ} \mathrm{E}, \mathrm{A} 95=7.6^{\circ}$ ) suggests rapid drift of Baltica between the intrusion of Egersund diabase dykes (616 Ma), and the time of deposition of the Hailuoto sediments (600 - $570 \mathrm{Ma}$ ). High plate velocity is a plausible cause for the rapid drift of Baltica during the Ediacaran, however considering the higher age limit of Hailuoto 
sediments (600 Ma), a non-actualistic geomagnetic field cannot be completely dismissed as a contributing factor in the large distances between Ediacaran poles. Our reconstructions of Baltica and Laurentia between $615 \mathrm{Ma}$ and $550 \mathrm{Ma}$, move Baltica from high latitudes (615 Ma), over the polar region, to an equatorial position $(550 \mathrm{Ma})$ and move Laurentia from low latitudes (615 Ma) to a polar position $(570 \mathrm{Ma})$ and back down to an equatorial position. A warm deposition environment and the lack of glaciogenic sediments determined in an earlier study of Hailuoto sediments, as well as the low to mid latitute position of Baltica determined by the Hailuoto paleomagnetic pole, indicate warm equatorial areas and cold polar areas, unlike in high obliquity models proposed for the Ediacaran.

\section{Acknowledgements}

Support for this work was provided by the Finnish Graduate School in Geology, the Vilho, Yrjö and Kalle Väisälä Foundation, and the Alfred Kordelin Foundation. We would like to acknowledge Juhani Ojala and Olli Breilin from the Geological Survey of Finland for initiating the Hailuoto project and Passi Heikkilä for his help. Finally, we would like to thank the reviewers for their valuable comments for improving this paper.

\section{References}

Abrajevitch, A. \& Van der Voo, R. 2010. Incompatible Ediacaran paleomagnetic directions suggest an equatorial geomagnetic dipole hypothesis. Earth and Planetary Science Letters 293, 164-170.

Bilardello, D., Kodama, K.P., 2010. Rock magnetic evidence for inclination shallowing in the early Carboniferous Deer Lake Group red beds of western Newfoundland. Geophysical Journal International 181, 275-289.

Bingen, B., Demaiffe, D., \& Van Breemen, O. 1998. The 616 Ma old Egersund basaltic dike swarm, SW Norway, and Late Neoproterozoic opening of the Iapetus Ocean. Journal of Geology 106, 565-574.

Bonhomme, M.G., Welin, E., 1983. Rb-Sr and K-Ar isotopic data on shale and siltstone from the Visingsö group, Lake Vättern basin, Geologiska Föreningen i Stockholm Förhandlingar 105, 363-366.

Borradaile, G.J., Luca, K., Middleton, R. S., 2004. Low-temperature demagnetization isolates stable magnetic vector components in magnetite-bearing diabase. Geophysical Journal International 157, 526-536. 
Buchan, K.L., 2013. Key paleomagnetic poles and their use in Proterozoic continent and supercontinent reconstructions: A review. Precambrian Research 238, 93-110.

Condon, D.J., Bowring, S.A., 2011. A user's guide to Neoproterozoic geochronology. In: Arnaud, E., Halverson, G.P., Shields-Zhou, G. (Eds.), The Geological Record of Neoproterozoic Glaciations: Geological Society of London, Memoir, 36, 135-139.

Dalziel, I. W. D. 1997. Neoproterozoic-Paleozoic geography and tectonics: review, hypothesis, environmental speculation. Geological Society of America Bulletin, 109, 16-42.

Domeier, M., Van der Voo, R., Torsvik, T.H., 2012. Paleomagnetism and Pangea: The road to reconciliation. Tectonophysics 514-517, 14-43.

Elming, S.-A., Kravchenko, S., Layer, P., Rusakov, O., Glevasskaya, A., Mikhailova, N., Bachtadse, V., 2007. Palaeomagnetism and 40Ar/39Ar age determinations of the Ediacaran traps from the southwestern margin of the East European Craton, Ukraine: relevance to the Rodinia break-up. Journal of the Geological Society (London) 164, 969982.

Eyles, N., and Januszczak, N., 2004. 'Zipper-rift': a tectonic model for Neoproterozoic glaciations during the breakup of Rodinia after 750 Ma. Earth-Science Reviews 65, 1-73.

Evans, D.A.D., 2003. True polar wander and supercontinents. Tectonophysics 362, 303-320.

Evans, D.A.D., 2006. Proterozoic low orbital obliquity and axial-dipolar geomagnetic filed from evaporate paleolatitudes. Nature 444, 51-55.

Evans, D.A.D., 2009. The palaeomagnetically viable, long-lived and all-inclusive Rodinia supercontinent reconstruction. Geological Society, London, Special Publications 327, 371-404.

Fedorova, N.M., Levashova, N.M., Meert, J.G., Maslov, A.V., Krupenin, M.T., 2014. New paleomagnetic data on Baltica based on upper Ediacaran deposits on the western slope of the Middle Urals. Doklady Earth Sciences 456, $512-$ 516.

Fisher, R., 1953. Dispersion of sphere. Proceedings of the Royal Society A 217, 293-305.

Geissman, J.W., Jackson, M., Harlan, S.S., Van der Voo, R., 2012. Paleomagnetism of Latest Cambrian-Early Ordovician and Latest Cretaceous-Early Tertiary rocks of the Florida Mountains, southwest New Mexico. Journal of Geophysical Research 96 B4, 6053-6071.

Golovanova, I. V., Danukalov, K. N., Kozlov, V. I., Puchkov, V. N., Pavlov, V. E., Gallet, Y., Levashova, N. M., Sirota, G. S., Khairullin, R. R., Bazhenov, M. L. 2011. Paleomagnetism of the Upper Vendian Basu Formation of the Bashkirian Meganticlinorium Revisited. Physics of the Solid Earth 47, $623-635$.

Gurnis, M., Torsvik, T.H., 1994. Rapid drift of large continents during the late Precambrian and Paleozoic: Paleomagnetic constraints and dynamic models. Geology 22, 1023-1026.

Halverson, G.P., 2006. A Neoproterozoic chronology. In: Xiao, S., Kaufman, A. (Eds.). Neoproterozoic Geobiology and Paleobiology. Vol. 27 of Topics in Geobiology.Springer, Dordrecht, The Netherlands, pp. 231-271.

Hoffman, P. F. 1991. Did the breakout of Laurentia turn Gondwanaland inside-out? Science, 252, 1409-1412.

Hoffman, P. F., Kaufman, A. J., Halverson, G. P. \& Schrag, D. P. A., 1998. Neoproterozoic snowball Earth. Science $281,1342--1346$.

Hoffman, P.F., Li, Z.X., 2009. A palaeogeographic context for Neoproterozoic glaciation. Palaeogeography, Palaeoclimatology, Palaeoecology 277, 158-172. 
Hoffman, P.F. \& Schrag, D.P. 2002. The snowball Earth hypothesis: testing the limits of global change. Terra Nova 14, 129-155.

Hyde, W.T., Crowley, T.J., Baum, S.K., Peltier. W.R., 2000. Neoproterozoic ‘snowball Earth' simulations with a coupled climate/ice-sheet model. Nature 405, 425-429.

Iglesia Llanos, M. P., Tait, J. A., Popov, V., Abalmassova, A. 2005. Palaeomagnetic data from Ediacaran (Vendian) sediments of the Arkhangelsk region, NW. Russia: An alternative apparent polar wander path of Baltica for the Late Proterozoic - Early Palaeozoic. Earth and Planetary Science Letter 240, 732 - 747.

Iosifidi, A. G., Khramov, A. N. 2005. Multicomponent magnetization of Vendian sedimentary rocks in Podolia, Ukraine. Russian Journal of Earth Sciences 7, 1 - 14.

Jackson, M.J., Banerjee, S.K., Marvin, J.A., Lu.R., Gruber, W., 1991. Detrital remanence, inclination errors and anhysteretic remanence anisotropy: quantitatively model and experimental results. Geophysical Journal International 104, 95-103.

Kalla, J., 1960. Muhoksen muodostuman alueella, Limingan Tupoksella suoritettu syväkairaus. Vuoriteollisuus Bergshanteringen, Vol. 18, No. 1. pp. 53- 54.

Khramov, A.N., Iosifidi, A.G. 2009. Paleomagnetism of the Lower Ordovician and Cambrian Sedimentary Rocks in the Sectio of the Narva River Right Bank: for the Construction of the Baltic Kinematic Model in the Early Paleozoic. Physics of the Solid Earth 45, $465-481$.

King, R.F., 1955. Remanent magnetism of artificially deposited sediments. Monthly Notices Royal Astronomical Society Geophysical Supplements 7, 115-134

Kirschvink, J.L. 1992. Late Proterozoic Low-Latitude Global Glaciation: The Snowball Earth. In: Schofp, J. W. \& Klein, C. (eds) The Proterozoic Biosphere. Cambridge University Press, Cambridge, 51-52.

Kirschvink, J.L., Ripperdan, R.L., Evans, D.A., 1997. Evidence for large-scale reorganization of early Cambrian continental masses by inertial interchange true polar wander. Science 277, 541-545.

Knoll, A.H. 1992. The early evolution of eukaryotes, a geological perspective. Science 256, 622-637.

Kodama, K.P., 2012. Paleomagnetism of Sedimentary Rocks: process and interpretation. Wiley-Blackwell.

Kohonen, J., Rämö, O.T., 2005. Sedimentary rocks, diabases, and late cratonic evolution, in: Lehtinen, M., Nurmi, P.A., Rämö, O.T. (Eds.), Precambrian Geology of Finland: Key to the Evolution of the Fennoscandian Shield. Elsevier B.V., Amsterdam, pp. 563-604.

Korja, A., Korja, T., Luosto, U., Heikkinen, P., 1993. Seismic and geoelectric evidence for collisional and extensional events in the Fennoscandian Shield implications for Precambrian crustal evolution. Tectonophysics 219, $129-152$.

Leino, M.A.H., 1991. Paleomagneettisten tulosten monikomponenytianyalyysi pienimmän neliösumman menetelmällä (Multicomponent analysis of paleomagnetic data by least-square method). Geological Survey of Finland Report Q29.1/91/2 (in Finnish).

Levashova, N.M., Bazhenov, M.L., Meert, J.G., Kuznetsov, N.B., Golovanova, I.V., Danukalov, K. N., Fedorova, N.M., 2013. Paleogeography of Baltica in the Ediacaran: Paleomagnetic and geochronological data from the clastic Zigan Formation, South Urals. Precambrian Research 236, 16-30.

Lewandowski, M., Abrahamsen, N., 2003. Paleomagnetic results from the Cambrian and Ordovician sediments of Bornholm (Denmark) and Southern Sweden and paleogeographical implications for Baltica. Journal of Geophysical Research 108, B11, 2516, doi:10.1029/2002JB002281 
Li, Z-X., Evans, D.A.D., Halverson, G.P., 2013. Neoproterozoic glaciations in a revised global palaeogeography from the breakup of Rodinia to the assembly of Gondwanaland. Sedimentary Geology 294, 219-232.

Lindgren, S., 1981. Remarks on the taxonomy, botanical affinities, and distribution of leiospheres. (Summary in Russian) Stockholm Contrib. Geol., 38(1): 1-20. Stockholm.

Lubnina N.V., Pisarevsky, S.A., Puchkov, V.N., Kozlov, V.I., Sergeeva, N.D., 2014. New paleomagnetic data from Late Neoproterozoic sedimentary successions in Southern Urals, Russia: implications for the Late Neoproterozoic paleogeography of the Iapetan realm. International Journal of Earth Sciences 103, 1317-1334.

McCausland, P.J.A., Hodych, J.P., 1998. Paleomagnetism of the 550 Ma Skinner Cove volcanics of western Newfoundland and the opening of the Iapetus Ocean. Earth and Planetary Science Letters 163, 15-29.

McCausland, P.J.A., Hankard, F., Van der Voo, R., Hall, C.M., 2011. Ediacaran paleogeography of Laurentia: paleomagnetism and ${ }^{40} \mathrm{Ar}-{ }^{39} \mathrm{Ar}$ geochronology of the 583 Ma Baie de Moutons syenite, Quebec. Precambrian Research 187, 58-78.

McCausland, P.J.A., Van der Voo, R., Hall, C.M., 2007. Circum-Iapetus paleogeography of the Precambrian-Cambrian transition with a new paleomagnetic constraint from Laurentia, Precambrian Research 156, 125-152

McFadden, P.L., McElhinny, M.W. 1990. Classification of the reversal test in palaeomagnetism. Geophysical Journal International 103, 725-729.

Meert, J.G., 1999. A palemagnetic analysis of Cambrian true polar wander. Earth and Planetary Science Letters 168 (12), 131-144.

Meert, J. 2014. Ediacaran-Early Ordovician paleomagnetism of Baltica: A review. Gondwana Research 25, 159-169.

Meert, J.G., Endale, T., Spearman, J., 2003. Non-dipole fields and inclination bias: insights from a random walk analysis. Earth and Planetary Science Letters 214, 395-408.

Meert, J.G., Tamrat, E., 2004. A mechanism for explaining rapid continental motion in the Late neoproterozoic, In : Eriksson, et al. (Ed.), The Precambrian Earth: Tempos and Events. Developments in Precambrian Geology, 12. Elsevier, Amsterdam, pp.255-266.

Meert, J.G., Torsvik, T.H., Eide, E.A., Dahlgren, S., 1998. Tectonic significance of the Fen Province, S. Norway: constraints from geochronology and pleomagnetism. Journal of Geology 106, 553-564.

Meert, J.G., Van der Voo, R., Payne, T.P., 1994. Paleomagnetism of the Cotaoctin Volcanic province: a new VendianCambrian apparent polar wander path for North America. Journal of Geophysical Research 99, 4625-4641.

Meert, J.G., Van der Voo, R., Powell, C.Mca., Li. Z.X., McElhinny, M.W., Chen, Z., Symons, D.T.A., 1993. A plate tectonic speed limit? Nature 363, 216-217.

Meert, J. G., Walderburg, H. J., Torsvik, T. H., Hendriks, B. W. H. 2007. Age and paleomagnetic signature of the Alnø carbonatite complex (NE Sweden): Additional controversy for the Neoproterozoic paleoposition of Baltica.

Precambrian Research 154, 159 - 174.

Mens, K., Pirrus, E., 1997. Vendian. In: Raukas, A., Teedumäe, A. (Eds.) Geology and mineral resources of Estonia. Estonian Academy Publishers, Tallinn, pp 35-38.

Micheels, A., Montenari, M., 2008. A snowball Earth versus a slushball earth: Results from Neoproterozoic climate modeling sensitivity experiments. Geosphere 4, 401-410.

Mitchell, R.N., Kilian, T.M., Raub, T.D., Evans, D.A.D., Bleeker, W., Maloof, A.C., 2011. Sutton hotspot track: resolving Ediacaran-Cambrian tectonics and true polar wander of Laurentia. American Journal of Science 311, 651-663 
Murthy, G.S., 1971. The paleomagnetism of diabase dikes from the Grenville Province. Canadian Journal of Earth Sciences 8, 802-812.

Murthy, G., Gower, C., Tubrett, M., Pätzold, R., 1992. Paleomagnetism of Eocambrian Long Range dykes and Double Mer Formation from Labrador, Canada. Canadian Journal of Earth Sciences 29, 1224-1234

Nawrocki, J., Boguckij, A., Katinas, V. 2004. New Late Vendian palaeogeography of Baltica and the TESZ. Geological Quarterly 48, 309-316.

Nikishin, A.M., Ziegler, P.A., Stephenson, R.A., Cloetingh, S.A.P.L, Furne, A.V., Fokin, P.A., Ershov, A.V., Bolotov, S.N., Korotaev, M.V., Alekseev, A.S., Gorbachev, V.I., Shipilov, E.V., Landkreijer, A., Bembinova, E. Yu., Shalimov, I.V., 1996. Late Precambrian to Triassic history of the East European Craton: dynamics of sedimentary basin evolution. Tectonophysics 268, 23-63.

Pesonen, L.J., Mertanen S., Veikkolainen, T., 2012. Paleo-Mesoproterozoic Supercontinents - A Paleomagnetic View. Geophysica 48, 5-48.

Piper, J.D.A., 1981. Magnetic properties of the Alnö Complex. Geoligiska Foreningen i Stockholm Forhandlinger 103, 9-15.

Pisarevsky, S.A., Murphy, J.B., Cawood, P.A., Collins, A.S., 2008. Late Neoproterozoic and Early Cambrian paleogeography: models and problems. In: Pankhurst, et al. (Ed.), West Gondwana: Pre-Cenozoic Correlations Across the South Atlantic Region: Geological Society of London Special Publication, 294, 9-31.

Popov, V., Iosifidi, A., Khramov, A. 2002. Paleomagnetism of Upper Vendian sediments from the Winter Coast, White Sea Region, Russia: Implications for the paleogeography of Baltica during Neoproterozoic times. Journal of Geophysical Research 107, doi:10.1029/2001JB001607.

Popov,V.V., Khramov, A.N., Bachtadse, V., 2005. Palaeomagnetism, magnetic stratigraphy, and petromagnetism of the Upper Vendian sedimentary rocks in the sections of the Zolotitsa River and in the Verkhotina Hole, Winter Coast of the White Sea, Russia. Russian Journal of Earth Sciences 7, 1-29.

Preeden, U., Mertanen, S., Elminen, T., Plado, J., 2009. Secondary magnetizations in shear and fault zones in southern Finland. Tectonophysics, 479(3-4), 203-213.

Puffer, J.H., 2002. A Late Neoproterozoic eastern Laurentian superplume: Location, size, chemical composition, and environmental impact: American Journal of Science, v. 302, p. 1-27

Puura, V., Amantov, A., Tikhomirov, S., Laitakari, I., 1996. Latest events affecting the Precambrian basement, Gulf of Finland and surrounding areas. In: Koistinen, T. (Ed.) Explanation to the Map of Precambrian Basement of the Gulf of Finland and Surrounding Areas, 1:1 mill. Espoo: Geological Survey of Finland. Special Paper 21, pp. 115-125.

Runnegar, B., 2000. Loophole for Snowball Earth. Nature 405, 403-404.

Rämö, O.T., Haapala, I., 2005.Rapakivi granites. In: Lehtinen, M., Nurmi, P.A., Rämö, O.T. (Eds.), Precambrian Geology of Finland - Key to the Evolution of the Fennoscandian Shield. Elsevier B.V., Amsterdam, pp. 533-562.

Simonen, A. 1960. Pre-Quaternary rocks in Finland. Bulletin de la Commission géologique de Finlande 191, 1-49.

Simonen, A., Kouvo, O., 1955. Sandstones in Finland. Extrait des Comptes Rendus de la Société géologique de Finlande 168, 57-87.

Smethurst, M. A., Khramov, A. N., Pisarevsky, S. 1998. Palaeomagnetism of the Lower Ordovician Orthoceras Limestone, St. Petersburg, and a revised drift history for Baltica in the early Palaeozoic. Geophysical Journal International 133, $44-56$. 
Solismaa, L., 2008. Hailuodon ja Muhoksen muodostumien sedimentologiasta ja strigrafiasta (On the sedimentology and stratigraphy of the Hailuoto and Muhos formations). M.Sc Thesis. University of Turku, p 106. (in Finnish).

Starmer, I.C., 1993. The Sveconorwegian Orogeny in Southern Norway, relative to deep crustal structures and events in the North Atlantic Proterozoic supercontinent. Norsk Geologisk Tidsskrift 73, 109-132.

Symons, D.T.A., Chiasson, A.D., 1991. Paleomagnetism of the Callander Complex and the Cambrian apparent polar wander path for North America. Canadian Journal of Earth Sciences 28, 355-363.

Tanczyk, E.I., Lapointe, P., Morris, W.A., Schmidt, P.W., 1987. A paleomagnetic study of the layered mafic intrusion at Sept-Îles, Quebec. Canadian Journal of Earth Sciences 24, 1431-1438.

Tauxe L., Kodama, K.P., Kent, D.V., 2008. Testing corrections for paleomagnetic inclination error in sedimentary rocks: A comparative approach. Physics of the Earth and Planetary Interiors 169, 152-165.

Tauxe, L., Kent, D.V., 1984. Properties of a detrital remanence carried by haematite from study of modern river depostis and laboratory redeposition sediments. Geophysical Journal of the Royal Astronomical Society 76, 543-561.

Tauxe, L., Kent, D.V., 2004. A simplified statistical model for the geomagnetic field and the detection of shallow bias in paleomagnetic inlinations: Was the ancient magnetic field dipolar? In: Channell, J.E.T. (Ed.) 'Timescales of the Paleomagnetic field', Vol. 145, American Geophysical Union, Washington, D.C., pp.101-116.

Torsvik, T.H., Lohmann, K.C., Sturt, B.A., 1995. Vendian glaciations and their relation to dispersal of Rodinia: Paleomagnetic constraints. geology 23, 727-730.

Torsvik, T. H. , Rehnström, E.F. 2001. Cambrian palaeomagnetic data from Baltica: implications for true polar wander and Cambrian palaeogeography. Journal of the Geological Society, London 158, 321- 329.

Torsvik, T.H, Smethurst, M., 1999. Plate tectonic modeling: virtual reality with GMAP. Computers \& Geosciences 25 , 395-402.

Torsvik, T.H., Van der Voo, R., Preeden, U., MacNiocaill, C., Steinberger, B., Doubrovine, P.V., Van Hinsbergen, D.J.J., Domeir. M., Gaina, C., Tohver, E., Meert, J.G., McCausland, P.J.A., Cocks., R.M., 2012. Phanerozoic polar wander, paleogeography and dynamics. Earth-Science Reviews 114, 325-368.

Tynni, R., Donner, J. 1980. A microfossil and sedimentation study of the Late Precambrian formation of Hailuoto, Finland. Geological Survey of Finland, Bulletin 311.

Tynni, R., Uutela, A., 1984. Microfossils from the Precambrian Muhos formation in Western Finland. Geological Survey of Finland, Bulletin 330.

Van der Voo, R., 1990. The reliability of paleomagnetic data. Tectonophysics 184, 1-9.

Veltheim, V. 1969. On the pre-Quarternary geology of the Bothnian Bay area in the Baltic Sea. Bulletin de la Commission Géologique de Finlande 239, 60p.

Viola, G., Henderson, I.H.C, Bingen, B., Hendriks, B.W.H., 2011. The Grenvillian-Sveconorwegian orogeny in Fennoscandia: Back-thrusting and extensional shearing along the "Mylonite Zone". Precambrian Research 189, 368388.

Walderhaug, H. J., Torsvik, T. H., Halvorsen, E. 2007. The Egersund dykes (SW Norway): a robust Early Ediacaran (Vendian) palaemagnetic pole from Baltica. Geophysical Journal International 168, 935 - 948.

Wannäs, K., 1989. Seismic stratigraphy and tectonic development of the Upper Proterozoic to Lower Paleozoic of the Bothnian Bay, Baltic Sea. Stockholm Contribution in Geology 40 (3), pp. 83-168.

Williams, G. E., 1975. Late Precambrian glacial climate and the Earth's obliquity. Geol. Mag. 112, 441--465. 
Williams, G. E., 1993. History of the Earth's obliquity. Earth Sci. Rev. 34,1--45.Zijderveld, J.D.A., 1967.

Demagnetization of Rocks: Analysis of Results, in: Collinson, D.V., Kreer, K.M., Runcorn, S.K. (Eds.), Methods in Palaeomagnetism. Elsevier, New York.

Williams, G.E., 2008. Proterozoic (pre-Ediacaran) glaciation and the high obliquity, low-latitude ice, strong seasonality (HOLIST) hypothesis: Principles and tests. Earth-Science Reviews 87, 61-93.

Zijderveld, J.D.A., 1967. Demagnetization of Rocks: Analysis of Results, in: Collinson, D.V., Kreer, K.M., Runcorn, S.K. (Eds.), Methods in Palaeomagnetism. Elsevier, New York. 


\section{FIGURE CAPTION:}

Fig.1. Location of Hailuoto and the Muhos formation. From Veltheim (1969).

Table 1. Mean paleomagnetic results from Hailuoto sediments.

Fig. 2. Examples of thermal (H5_1887A and H5_1471A) demagnetization of Hailuoto sediment specimens. On stereoplots (A), solid symbols represent lower hemisphere vectors, and open symbols represent upper hemisphere vectors. B is the intensity plots $\left(\mathrm{J} / \mathrm{J}_{0}\right)$ of thermal demagnetization. On orthogonal projection diagrams $(\mathrm{C})$, solid symbols show projections onto the horizontal plane, and open symbols show projections onto the vertical plane. H5_1887A = normal polarity ChRM, H5_1471A = reversed polarity ChRM, H5_1334A = steep secondary component (DiRM), and H5_1012A $=$ secondary component $\mathrm{B}$.

Fig. 3. Left: Stereoplot showing the paleomagnetic results of the ChRM (observed) component. Right: Mean directions, including the secondary components; normal and reversed directions of the ChRM are combined in a single mean direction. Solid symbols represent lower hemisphere vectors, and open symbols represent upper hemisphere vectors. PEF indicates the present day magnetic field direction for Hailuoto.

Fig. 4. Stratigraphy of the drill core (M52-HAIL-04-005), and magnetic inclination of ChRM along the depth profile. Geological log by Solismaa (2008).Colors in the inclination column: black (white) indicates normal (reversed) polarity. Grey indicates the lack of stable paleomagnetic data. Black dots indicate all the measured samples.

Fig. 5. Thermomagnetic curves (susceptibility vs. temperature) for Hailuoto sediment samples, indicating magnetite and hematite as the magnetic carriers. Solid line indicates heating curve and the dotted line indicates the cooling curve.

Table 2. Selected Ediacaran poles and Ordovician poles for Baltica

Fig. 6. APWP of (A) Baltica and (B) Laurentia. The Hailuoto ChRM pole is marked in green. A and B grade poles are indicated by red and orange respectively. Numbers in bold indicate age in Ma.

Fig. 7. Reconstructions of Baltica and Laurentia between 615 -550 Ma. Baltica shown observed (obs.) and inclination corrected (i.c.) positions in 550 Ma reconstruction. Euler poles provided in Table 3.

Table 3. Paleomagnetic poles used for the reconstruction in Fig 7. 


\begin{tabular}{|c|c|c|c|c|c|c|c|c|c|c|}
\hline Sample & Lith. & $\mathrm{N} / \mathrm{n}$ & $\begin{array}{r}\text { Dec } \\
\left({ }^{\circ}\right)\end{array}$ & $\begin{array}{l}\text { Inc } \\
\left({ }^{\circ}\right)\end{array}$ & $\begin{array}{l}\alpha_{95} \\
\left({ }^{\circ}\right)\end{array}$ & $\mathrm{k}$ & $\begin{array}{l}\text { Plat } \\
\left({ }^{\circ} \mathrm{N}\right)\end{array}$ & $\begin{array}{l}\text { Plon } \\
\left({ }^{\circ} \mathrm{E}\right)\end{array}$ & $\begin{array}{r}\text { A95 } \\
\left({ }^{\circ}\right)\end{array}$ & $\mathrm{K}$ \\
\hline \multicolumn{11}{|c|}{ Hailuoto ChRM component. normal polarity } \\
\hline H5_626 & Ms & $1 / 1$ & 301.1 & 24.2 & & & 24.3 & 271.2 & & \\
\hline H5_655 & Ms & $1 / 4^{*}$ & 293.9 & 48.1 & 16.1 & 33.4 & 36.2 & 286.5 & 18.6 & 25.4 \\
\hline H5_797 & $\mathrm{sCSs}$ & $1 / 1$ & 341.2 & 31.7 & & & 40.5 & 228.7 & & \\
\hline H5_1259 & $\mathrm{SC}$ & $1 / 1$ & 318.0 & 33.8 & & & 35.8 & 256.3 & & \\
\hline H5-1468 & MSs & $1 / 1$ & 342.3 & 58.6 & & & 62.3 & 235.2 & & \\
\hline H5_1471 & MSs & $1 / 1$ & 336.6 & 41.1 & & & 45.8 & 236.3 & & \\
\hline H5-1489 & $\mathrm{CSs}$ & $1 / 1$ & 335.4 & 37.7 & & & 43.2 & 237.0 & & \\
\hline $\operatorname{Mean} \operatorname{ChRM}(N)$ & & $* 7 / 10$ & 323.5 & 40.7 & 14.5 & 18.8 & 43.0 & 252.0 & 15.4 & 16.4 \\
\hline $\operatorname{Mean}(f=0.6)$ & & & 323.1 & 54.2 & 12.0 & 26.3 & 53.9 & 259.2 & 14.8 & 17.6 \\
\hline \multicolumn{11}{|c|}{ Hailuoto ChRM component. reversed polarity } \\
\hline H5_612 & Ms & $1 / 1$ & 196.2 & -35.2 & & & -43.1 & 3.7 & & \\
\hline H5_1334 & $\mathrm{CSs}$ & $1 / 1$ & 161.0 & -44.0 & & & -48.9 & 51.3 & & \\
\hline H5_1420 & MSs & $1 / 1$ & 171.6 & -32.7 & & & -42.4 & 35.6 & & \\
\hline H5-1439 & MSs & $1 / 1$ & 171.6 & -25.4 & & & -38.0 & 35.2 & & \\
\hline H5_1531 & $\mathrm{sCSs}$ & $1 / 1$ & 132.3 & -33.8 & & & -33.8 & 82.4 & & \\
\hline H5_1551 & $\mathrm{SC}$ & $1 / 1$ & 178.5 & -60.3 & & & -66.2 & 27.6 & & \\
\hline H5_1581 & $\mathrm{SC}$ & $1 / 1$ & 127.8 & -50.2 & & & -43.5 & 93.8 & & \\
\hline H5-1598 & $\mathrm{SC}$ & $1 / 1$ & 154.9 & -40.3 & & & -44.9 & 58.2 & & \\
\hline H5-1650 & $\mathrm{SC}$ & $1 / 1$ & 149.9 & -39.0 & & & -42.7 & 64.0 & & \\
\hline H5_1656 & $\mathrm{SC}$ & $1 / 1$ & 150.1 & -67.9 & & & -69.1 & 86.7 & & \\
\hline H5_1678 & $\mathrm{SC}$ & $1 / 1$ & 187.8 & -33.1 & & & -42.7 & 14.7 & & \\
\hline H5_1693 & $\mathrm{SC}$ & $1 / 1$ & 158.5 & -64.7 & & & -68.2 & 67.5 & & \\
\hline H5_1702 & $\mathrm{SC}$ & $1 / 2$ & 116.2 & -39.1 & & & -30.9 & 100.5 & & \\
\hline H5_1842 & $\mathrm{SC}$ & $1 / 1$ & 156.4 & -35.9 & & & -42.2 & 55.3 & & \\
\hline H5_1852 & $\mathrm{SC}$ & $1 / 1$ & 191.7 & -40.3 & & & -47.2 & 8.8 & & \\
\hline H5_1863 & $\mathrm{SC}$ & $1 / 1$ & 166.5 & -36.4 & & & -44.3 & 42.6 & & \\
\hline H5_1887 & $\mathrm{SC}$ & $1 / 2$ & 157.4 & -43.2 & & & -47.5 & 55.8 & & \\
\hline H5_1930 & $\mathrm{SC}$ & $1 / 1$ & 122.9 & -53.9 & & & -44.6 & 101.2 & & \\
\hline H5-1979 & $\mathrm{SC}$ & $1 / 1$ & 139.3 & -47.4 & & & -45.6 & 79.7 & & \\
\hline \multicolumn{2}{|l|}{ Mean ChRM (R) } & \multirow[t]{2}{*}{$* 19 / 21$} & 158.5 & -45.5 & 8.5 & 16.5 & -49.5 & 55.1 & 9.7 & 12.8 \\
\hline $\operatorname{Mean}(f=0.6)$ & & & 158.5 & -58.7 & 6.7 & 26.1 & -61.6 & 60.4 & 9 & 14.9 \\
\hline \multicolumn{2}{|l|}{$\operatorname{Mean} \operatorname{ChRM}(C)$} & \multirow{2}{*}{$* 26 / 31$} & 334.2 & 44.4 & 7.2 & 16.5 & 48.7 & 241.1 & 8.1 & 13.2 \\
\hline $\operatorname{Mean}(f=0.6)$ & & & 334.4 & 57.7 & 5.8 & 25.2 & 60.5 & 247.9 & 7.6 & 15.0 \\
\hline \multicolumn{11}{|c|}{ Hailuoto secondary component. steep } \\
\hline H5_605 & Ms & $1 / 1$ & 240.4 & 42.7 & & & 11.0 & 331.3 & & \\
\hline H5_609 & Ms & $1 / 2$ & 219.3 & 48.8 & & & 9.6 & 350.9 & & \\
\hline H5_626 & Ms & $1 / 1$ & 257.3 & 75.1 & & & 49.2 & 340.3 & & \\
\hline H5_645 & Ms & $1 / 1$ & 198.8 & 78.2 & & & 43.1 & 15.0 & & \\
\hline H5_664 & Ms & $1 / 1$ & 209.7 & 59.5 & & & 17.9 & 1.4 & & \\
\hline
\end{tabular}




\begin{tabular}{|c|c|c|c|c|c|c|c|c|c|c|}
\hline H5_797 & sCSs & $1 / 1$ & 291.2 & 51.4 & & & 37.6 & 290.9 & & \\
\hline H5_1183 & $\mathrm{SC}$ & $1 / 2$ & 210.4 & 61.8 & & & 20.6 & 1.5 & & \\
\hline H5_1259 & $\mathrm{SC}$ & $1 / 1$ & 206.7 & 74.2 & & & 37.1 & 8.7 & & \\
\hline H5_1307 & sCSs & $1 / 1$ & 215.7 & 70.8 & & & 33.2 & 1.3 & & \\
\hline H5_1334 & $\mathrm{CSs}$ & $1 / 1$ & 285.8 & 67.9 & & & 50.9 & 310.6 & & \\
\hline H5_1345 & $\mathrm{CSs}$ & $1 / 1$ & 251.8 & 65.8 & & & 35.9 & 333.2 & & \\
\hline H5_2328 & $\mathrm{CSs}$ & $1 / 3^{*}$ & 246.5 & 74.4 & 23.9 & 27.6 & 45.3 & 345.4 & 43.6 & 9.0 \\
\hline H5_2428 & WB & $1 / 2$ & 255.8 & 66.8 & & & 38.4 & 331.2 & & \\
\hline $\begin{array}{l}\text { Mean sece } \\
\text { steep }\end{array}$ & & $13 * / 18$ & 239.0 & 67.3 & 8.7 & 23.9 & 35.2 & 344.5 & 12.5 & 12.0 \\
\hline \multicolumn{11}{|c|}{ Hailuoto secondary component $B$} \\
\hline H5_645 & Ms & $1 / 3^{*}$ & 45.7 & 28.1 & 33.8 & 14.3 & 31.2 & 150.8 & 40.6 & 10.3 \\
\hline H5_655 & Ms & $1 / 1$ & 53 & 47.2 & & & 40.9 & 136.5 & & \\
\hline H5_797 & sCSs & $1 / 1$ & 47.3 & 32.5 & & & 33.2 & 148.0 & & \\
\hline H5_1012 & SMs & $1 / 1$ & 45.7 & 28.1 & & & 31.2 & 150.8 & & \\
\hline H5_1396 & CSs & $1 / 1$ & 56.7 & 38.4 & & & 33.3 & 136.4 & & \\
\hline $\begin{array}{l}\text { Mean sece } \\
B\end{array}$ & & $5 * / 7$ & 49.4 & 34.9 & 8.6 & 80.7 & 34.1 & 144.7 & 6.9 & 122.8 \\
\hline
\end{tabular}

Sample is the sample number (H5 refers to the drill core, and the number following it to the depth in decimetre); N/n are number of samples/specimens; Lith. is lithology (Ms - mudstone, SMs - sandy mudstone, MSs - muddy sandstone, sCSs - slightly conglomeratic sandstone, CSs - conglomeratic sandstone, SC - sandy conglomerate, WB - weathered bedrock); Dec and Inc are magnetic declination and inclination; $\alpha_{95}$ and $\mathrm{k}$ are the confidence limit (95\%) and precision parameter respectively of the magnetic component; Plat and Plong are the paleo-latitude and longitude; A95 and K are the confidence limit (95\%) and precision parameter of the paleopole. 


\begin{tabular}{|c|c|c|c|c|c|c|c|c|c|c|}
\hline Formation & Inc & $\begin{array}{l}\text { Plat } \\
(\mathrm{N})\end{array}$ & $\begin{array}{l}\text { Plon } \\
\text { (E) }\end{array}$ & $\mathrm{dp}$ & $\mathrm{dm}$ & A95 & $\mathrm{Q}_{(1-6)}$ & Class & $\begin{array}{l}\text { Age } \\
(\mathrm{Ma})\end{array}$ & Ref \\
\hline $\begin{array}{l}\text { Narva limestones, } \\
\text { comp } \mathrm{C} 1\end{array}$ & & 18 & 55 & 5 & 7 & 5.9 & $011011=4$ & $\mathrm{C}$ & 475 & $\begin{array}{l}\text { Khramov and Iosifidi } \\
(2009)\end{array}$ \\
\hline $\begin{array}{l}\text { St Petersburg } \\
\text { limestone, comp. Pr }\end{array}$ & & 34.7 & 59.1 & 5.7 & 6.4 & 6.0 & $011110=4$ & $\mathrm{~B}$ & 478 & Smethurst et al. (1998) \\
\hline \multirow{2}{*}{$\begin{array}{l}\text { Narva sediments, } \\
\text { comp. C2 }\end{array}$} & obs. & 22 & 87 & 5 & 6 & 5.5 & \multirow{2}{*}{$011011=4$} & \multirow{2}{*}{$\mathrm{C}$} & \multirow{2}{*}{500} & \multirow{2}{*}{$\begin{array}{l}\text { Khramov and Iosifidi } \\
\text { (2009) }\end{array}$} \\
\hline & i.c. & 33.6 & 77.2 & & & & & & & \\
\hline \multirow{2}{*}{ Andarum-alum shale } & obs. & 52 & 111 & 7 & 10 & 8.4 & \multirow{2}{*}{$001010=2$} & \multirow{2}{*}{$\mathrm{D}$} & \multirow{2}{*}{500} & \multirow{2}{*}{$\begin{array}{l}\text { Torsvik \& Rehnström } \\
\text { (2001) }\end{array}$} \\
\hline & i.c. & 60.4 & 89.4 & & & & & & & \\
\hline \multirow{2}{*}{ Tornetrask formation } & obs. & 56 & 116 & 12 & 15 & 13.4 & \multirow{2}{*}{$001011=3$} & \multirow{2}{*}{$\mathrm{C}$} & \multirow{2}{*}{535} & \multirow{2}{*}{$\begin{array}{l}\text { Torsvik \& Rehnström } \\
\text { (2001) }\end{array}$} \\
\hline & i.c. & 66.1 & 96.9 & & & & & & & \\
\hline \multirow{2}{*}{ Nekso sandstone } & obs. & 40 & 170 & & & 5.1 & \multirow{2}{*}{$011010=3$} & \multirow{2}{*}{$\mathrm{C}$} & \multirow{2}{*}{545} & \multirow{2}{*}{$\begin{array}{l}\text { Lewandowski and } \\
\text { Abrahamsen (2003) }\end{array}$} \\
\hline & i.c. & 43.7 & 169 & & & & & & & \\
\hline $\begin{array}{l}\text { Zigan formation } \\
\text { clastic rocks -C }\end{array}$ & obs. & 16.2 & 318.4 & & & 4.1 & $111011=5$ & $\mathrm{~B}$ & $\begin{array}{r}547.6 \\
\pm 3.8 \\
\end{array}$ & Levashova et al. (2013) \\
\hline \multirow[b]{2}{*}{$\begin{array}{l}\text { Verkhotina } \\
\text { sediments, comp. Z }\end{array}$} & obs. & 31.7 & 292.9 & 1.6 & 2.7 & 2.1 & \multirow[b]{2}{*}{$111111=6$} & \multirow[b]{2}{*}{$\mathrm{A}$} & \multirow{2}{*}{$\begin{array}{r}550.2 \\
\pm 4.6 \\
550 \\
\pm 5.3 \\
\end{array}$} & \multirow[b]{2}{*}{ Popov et al. (2005) } \\
\hline & i.c. & 42.5 & 293.0 & & & & & & & \\
\hline \multirow[b]{2}{*}{$\begin{array}{l}\text { Zolotitca sediments, } \\
\text { comp. B }\end{array}$} & obs. & 28.3 & 290.0 & 2.5 & 4.4 & 3.3 & & & 550.2 & \\
\hline & i.c. & 41.4 & 299.0 & & & & $111011=5$ & $\mathrm{~B}$ & $\begin{array}{r} \pm 4.6 \\
550 \\
\pm 5.3\end{array}$ & Iglesia Llanos et al. (2005) \\
\hline $\begin{array}{l}\text { Volhyn lavas - } \\
\text { combined }\end{array}$ & & 20.0 & 4.4 & & & 28.3 & $001011=3$ & $\mathrm{C}$ & $\begin{array}{r}561- \\
580 \\
\end{array}$ & Elming et al. (2007) \\
\hline Winter coast & obs. & 25.3 & 312.2 & 2.3 & 3.7 & 2.9 & $111011=5$ & $\mathrm{~B}$ & $555 \pm$ & Ponovetal (2002) \\
\hline sediments, com. Z & i.c. & 36.1 & 319 & & & & $111011=5$ & Б & & Popov el al. (2002) \\
\hline $\begin{array}{l}\text { Chernokamenskay } \\
\text { group sediments -C }\end{array}$ & obs. & 17.3 & 306.7 & & & 6.0 & $111011=5$ & B & $\begin{array}{r}557 \pm \\
13 \\
\end{array}$ & Fedorova et al. (2014) \\
\hline Podolia comn V & obs. & 40.0 & 276.5 & & & 7.5 & $011011=4$ & $C$ & $545-$ & Iocifidietal (2005) \\
\hline rodorra, comp. v & i.c. & 47.9 & 285.5 & & & & $011011=4$ & C & 570 & Iosinial et al. (2005) \\
\hline Basu-Kukkarauk & obs. & -1.1 & 7.3 & & & 5.8 & $111011-5$ & $\mathrm{P}$ & 560 & Goloyonoye at al (2011) \\
\hline formation $-\mathrm{C}$ & i.c. & 3.5 & 22.4 & & & & $111011=5$ & Б & 500 & Golovanova et al. (2011) \\
\hline $\begin{array}{l}\text { Krivaya Luka } \\
\text { formation }\end{array}$ & & 58.6 & 275.8 & 4.8 & 7.7 & 6.1 & $111011=5$ & $\mathrm{~B}$ & $\begin{array}{r}560- \\
570 \\
\end{array}$ & Lubnina et al. (2014) \\
\hline $\begin{array}{l}\text { Kurgashlya } \\
\text { formation }\end{array}$ & & 50.9 & 314.5 & 4.4 & 6.4 & 5.3 & $111011=5$ & $\mathrm{~B}$ & $\begin{array}{r}560- \\
570 \\
\end{array}$ & Lubnina et al. (2014) \\
\hline Bakeevo formation & & 42.3 & 299.1 & 4 & 6.9 & 5.3 & $111111=6$ & $\mathrm{~A}$ & $\begin{array}{r}560- \\
570 \\
\end{array}$ & Lubnina et al. (2014) \\
\hline Fen Complex & & 53.2 & 145.7 & & & 5.6 & $111001=4$ & $\mathrm{C}$ & $\begin{array}{r}583 \pm \\
15 \\
\end{array}$ & $\begin{array}{l}\text { Meert et al. (1998); Luleå } \\
\text { working group new mean }\end{array}$ \\
\hline $\begin{array}{l}\text { Alnö carbonate } \\
\text { complex (steep) }\end{array}$ & & 62.7 & 101.2 & 12.3 & 14.3 & 13.3 & $111010=4$ & $\mathrm{C}$ & $584 \pm$ & Meert et al. (2007) \\
\hline $\begin{array}{l}\text { Alnö carbonate } \\
\text { complex (shallow) }\end{array}$ & & 3.5 & 269.0 & 16.5 & 32.5 & 23.2 & $001010=2$ & $\mathrm{D}$ & & Meert et al. (2007) \\
\hline Hailueto sediments & obs. & 48.7 & 241.1 & & & 8.1 & $=4$ & $C$ & $600-$ & his study \\
\hline Malluoto sedments & i.c. & 60.5 & 247.9 & & & 7.6 & $011011-4$ & C & 570 & ImIs studuy. \\
\hline Egersund dykes & & 31.4 & 44.1 & 14.4 & 17 & 15.6 & $111110=5$ & $\mathrm{~A}$ & \begin{tabular}{|r|}
$616 \pm$ \\
3 \\
\end{tabular} & \begin{tabular}{|l|} 
Walderhaug et al. (2007), \\
Bingen et al. (1998) \\
\end{tabular} \\
\hline & obs. & 24.3 & 88.5 & 17.1 & 24.9 & 20.6 & & & & \\
\hline Nyborg formation & i.c. & 38.3 & 82.1 & & & & $101110=4$ & $\mathrm{~B}$ & $\begin{array}{r}653 \pm \\
7\end{array}$ & Torsvik et al. (1995) \\
\hline
\end{tabular}

Inc. indicates inclination status for sedimentary formation where obs. $=$ observed, and i.c. $=$ inclination correction of $\mathrm{f}=0.6$ following Torsvik et al. (2012); Plat/Plong = pole latitude/longitude; A95 = confidence circle of the pole; $\mathrm{Q}_{1-6}=$ 
Van der Voo reliability criteria (1 to 6) of paleomagnetic poles (Van der Voo, 1990), Class = quality of pole (Meert, 2014). 


\begin{tabular}{|c|c|c|c|c|c|c|c|c|}
\hline \multirow{2}{*}{\multicolumn{2}{|c|}{ Formation }} & \multirow{2}{*}{$\begin{array}{l}\text { Plat } \\
\left({ }^{\circ} \mathrm{N}\right)\end{array}$} & \multirow{2}{*}{$\begin{array}{l}\text { Plon } \\
\left({ }^{\circ} \mathrm{E}\right)\end{array}$} & \multicolumn{3}{|c|}{ Euler poles } & \multirow{2}{*}{$\begin{array}{l}\text { Age } \\
(\mathrm{Ma})\end{array}$} & \multirow[t]{2}{*}{ Reference } \\
\hline & & & & Lat & Long & angle & & \\
\hline \multicolumn{9}{|l|}{ Baltica } \\
\hline Egersund dykes & & -31 & 224 & -13 & 109 & 127 & $616 \pm 3$ & $\begin{array}{l}\text { Walderhaug et al. (2007), } \\
\text { Bingen et al. (1998) }\end{array}$ \\
\hline Hailuoto & obs. & -49 & 61 & -12 & 294 & 147 & & \\
\hline sediments & i.c. & -61 & 68 & -10 & 296 & 159 & $600-570 \mathrm{Ma}$ & This study \\
\hline Mean $570 \mathrm{Ma}$ & & -52 & 118 & 18 & 96 & 166 & 570 & *1 This study \\
\hline & $o b s$. & -30 & 111 & 16 & 51 & 129 & 550 & $*^{2}$ This study \\
\hline Mean $550 \mathrm{Ma}$ & i.c. & -42 & 116 & 13 & 56 & 139 & 550 & \\
\hline \multicolumn{9}{|l|}{ Laurentia } \\
\hline Long Range dykes & & -19 & 175 & 0 & 265 & -109 & $615 \pm 2$ & Murthy et al.1992 \\
\hline Baie de Mouton (A & & -43 & 153 & 0 & 243 & -133 & & McCausland et al. 2011 \\
\hline Baie de Mouton (B & & 34 & 142 & 0 & 52 & 56 & $583 \pm 2$ & \\
\hline $\begin{array}{l}\text { *Callandar alkaline } \\
\text { complex }\end{array}$ & & -46 & 121 & & & & $575 \pm 5$ & Symons and Chiasson (1991) \\
\hline Catoctin Basalts & & -42 & 117 & 0 & 207 & -132 & $572 \pm 5$ & Meert et al. 1994 \\
\hline Sept Iles intrusion & & 20 & 142 & 0 & 52 & 70 & $565 \pm 4$ & Tanczyk et al. 1987 \\
\hline Skinner Cove & & 16 & 175 & 0 & 85 & 74 & $550 \pm 3$ & McCausland and Hodych, 1998 \\
\hline $\begin{array}{l}\text { *Florida Mountains } \\
\text { auriole }\end{array}$ & & -6 & 169 & & & & $503 \pm 10$ & Geissman et al. (2012) \\
\hline
\end{tabular}

Plat, Plon is latitude and longitude of the paleomagnetic pole. The Euler poles are used in the reconstruction in Fig.7. *1 The 570 Ma mean pole was calculated from the Krivaya Luka, Kurgashlya and Bakeevo poles (Lubnina et al., 2014). *2 The 550 Ma mean pole was calculated from the Verkhotina comp. Z (Popov et al., 2005) and Zolotitca comp. B (Iglesia Llanos et al., 2005) poles. Laurentia poles marked with * were included in the APWP of Laurentia (Fig. 6B), but not in the reconstruction (Fig . 7), therefore the euler poles are not provided for them. 

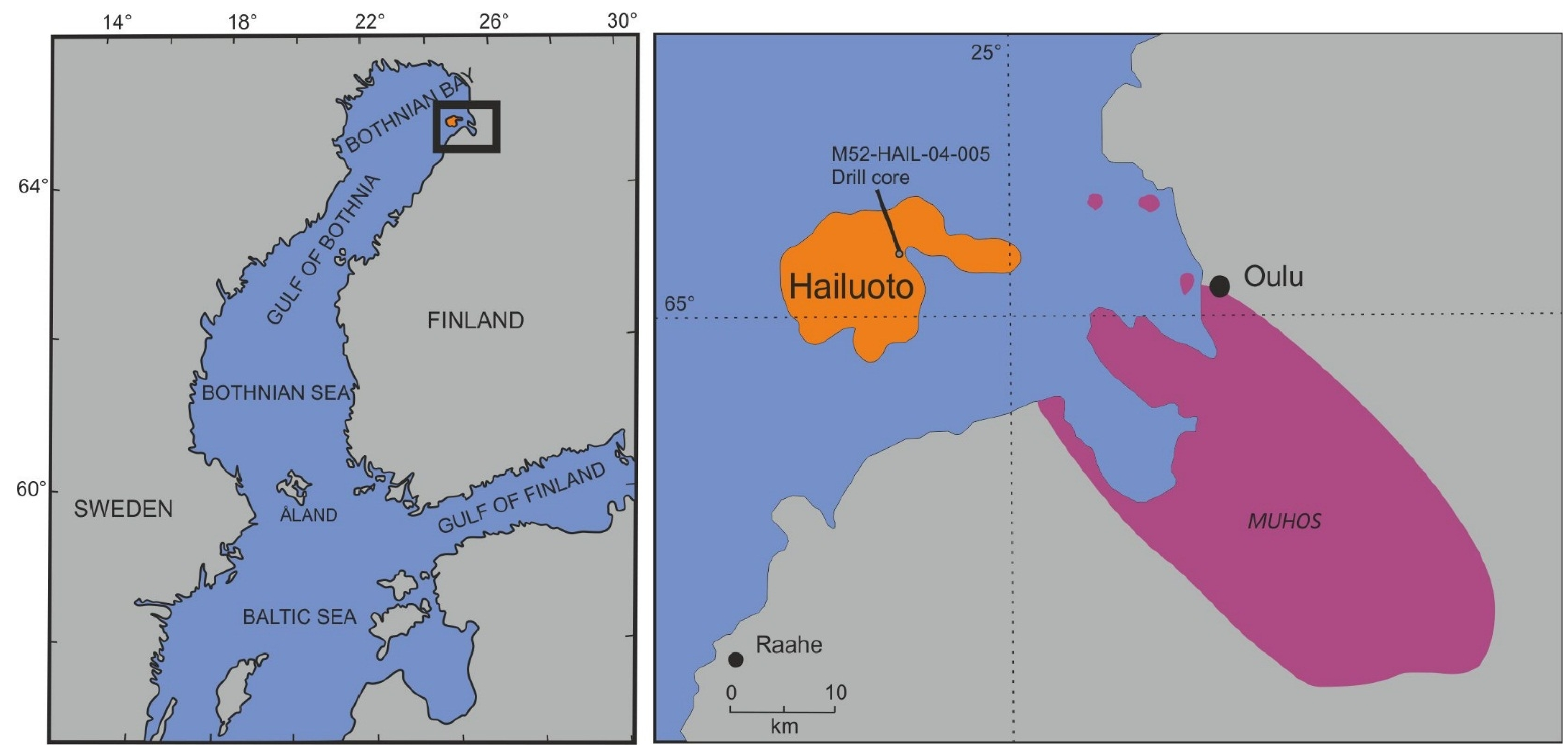

Fig 1.
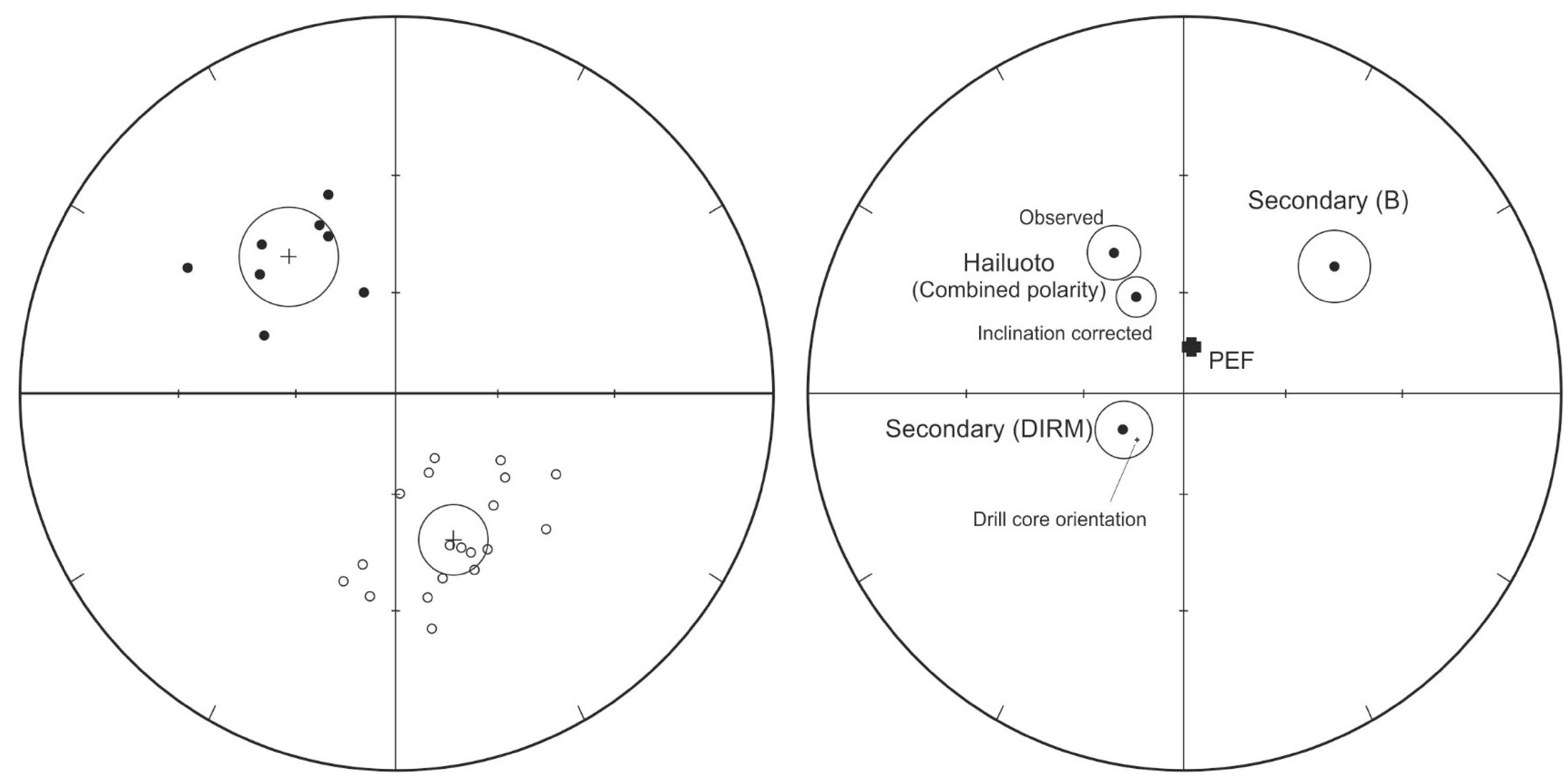

Primary (observed)

Mean directions

Fig. 3 

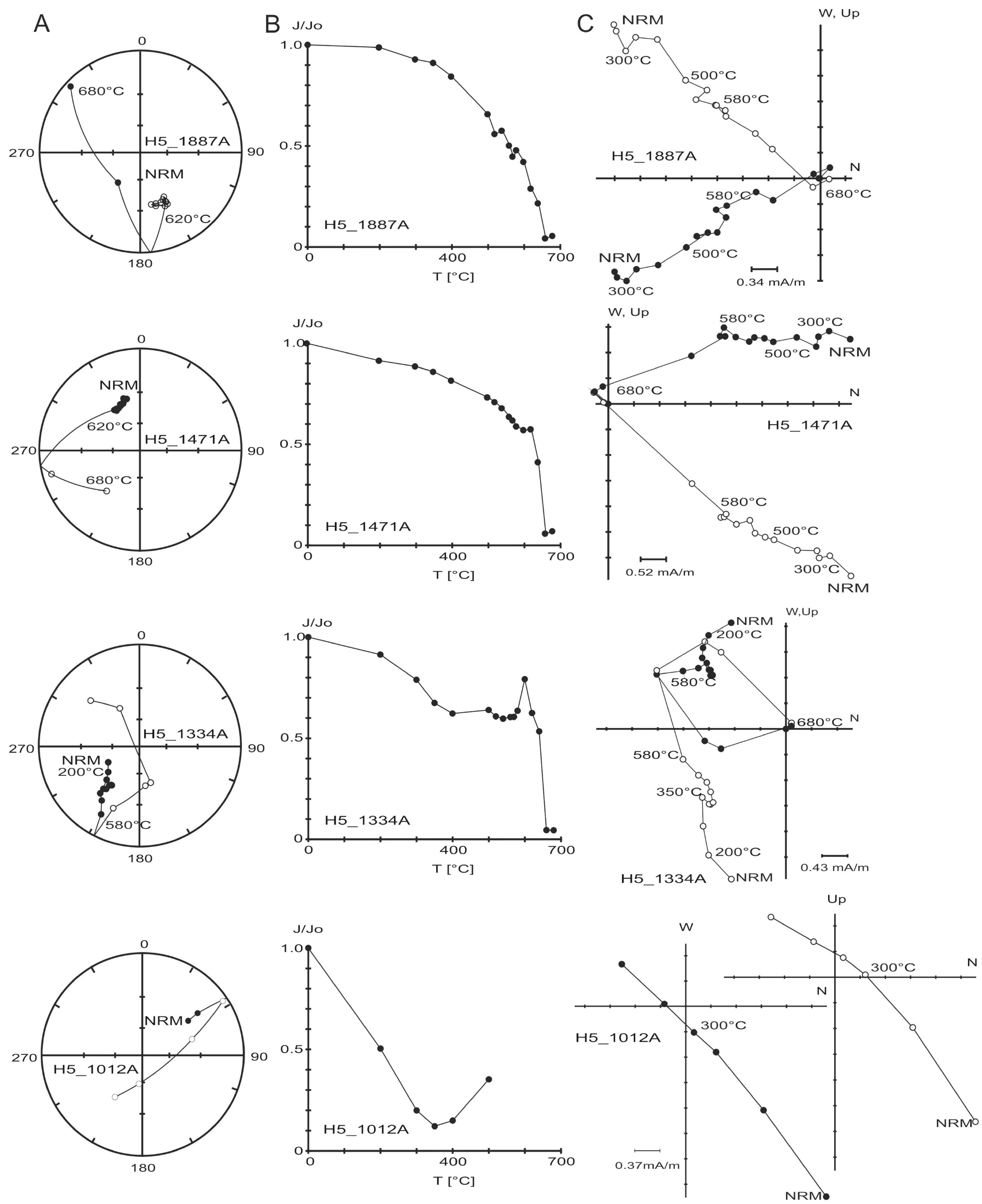

Fig. 2 


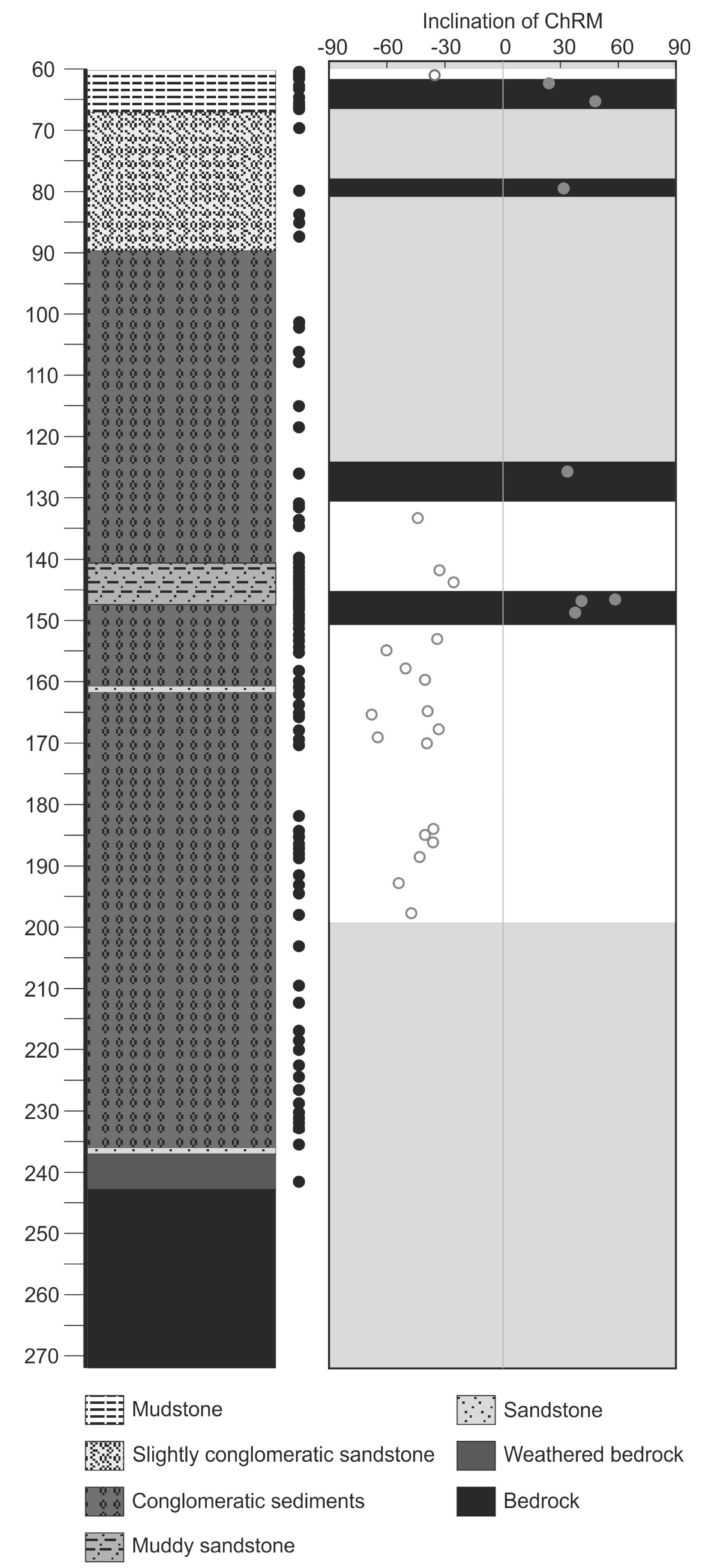

Fig. 4 

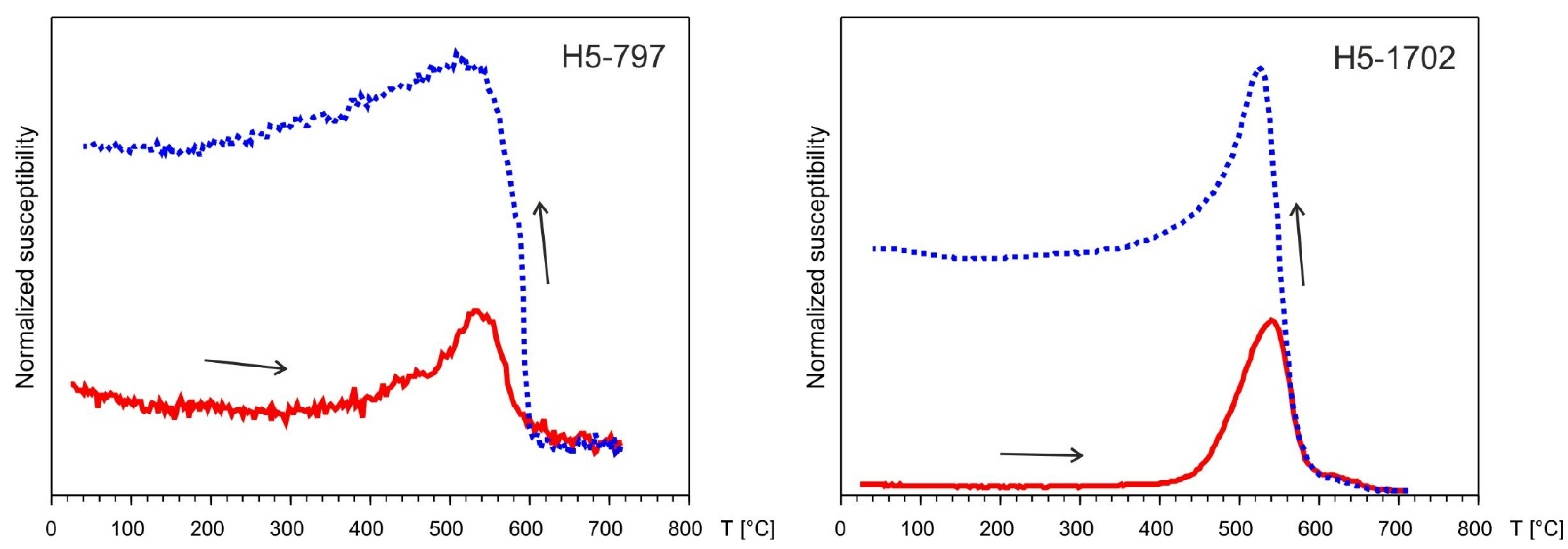

Fig. 5
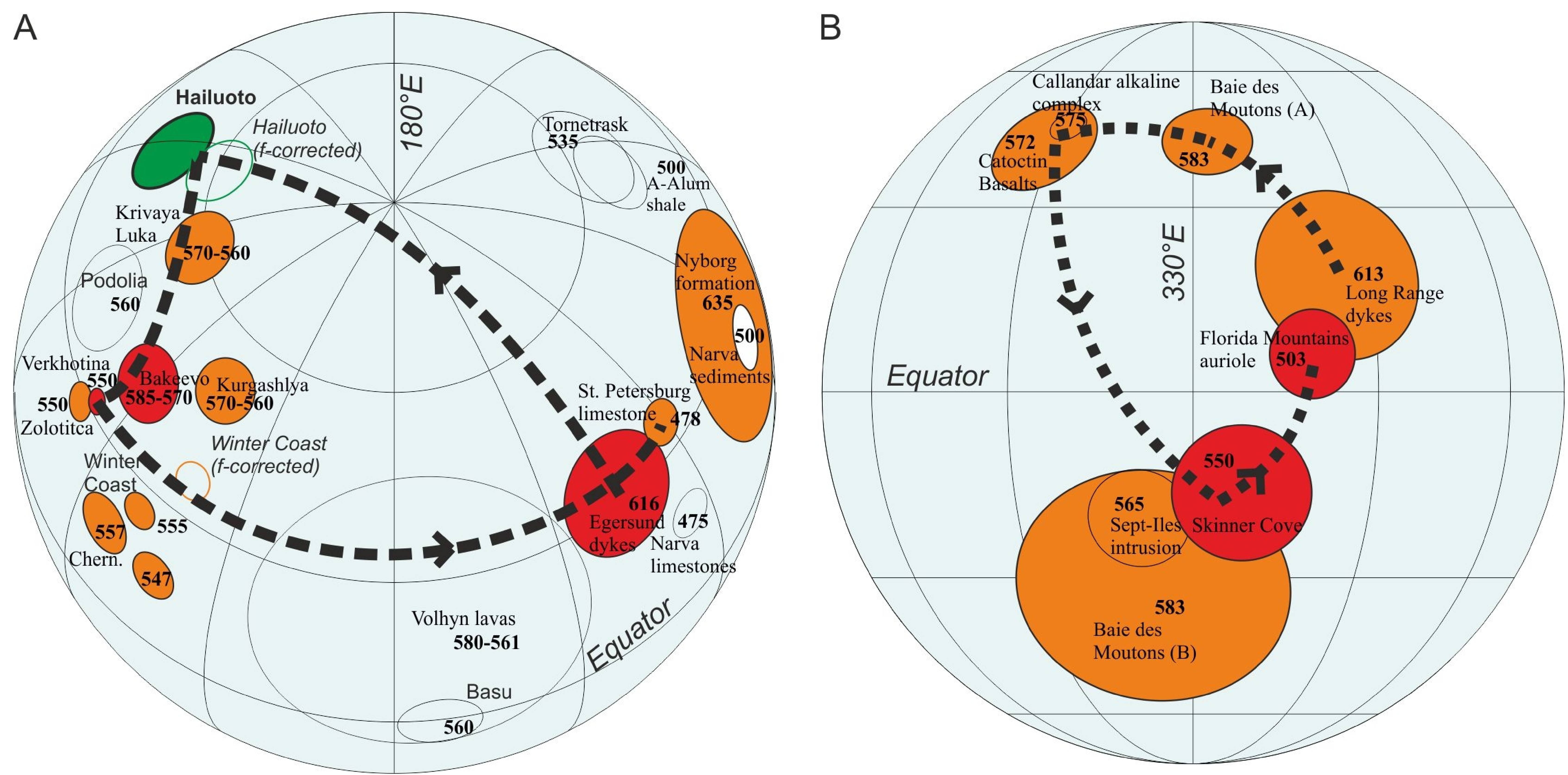

Fig. 6 


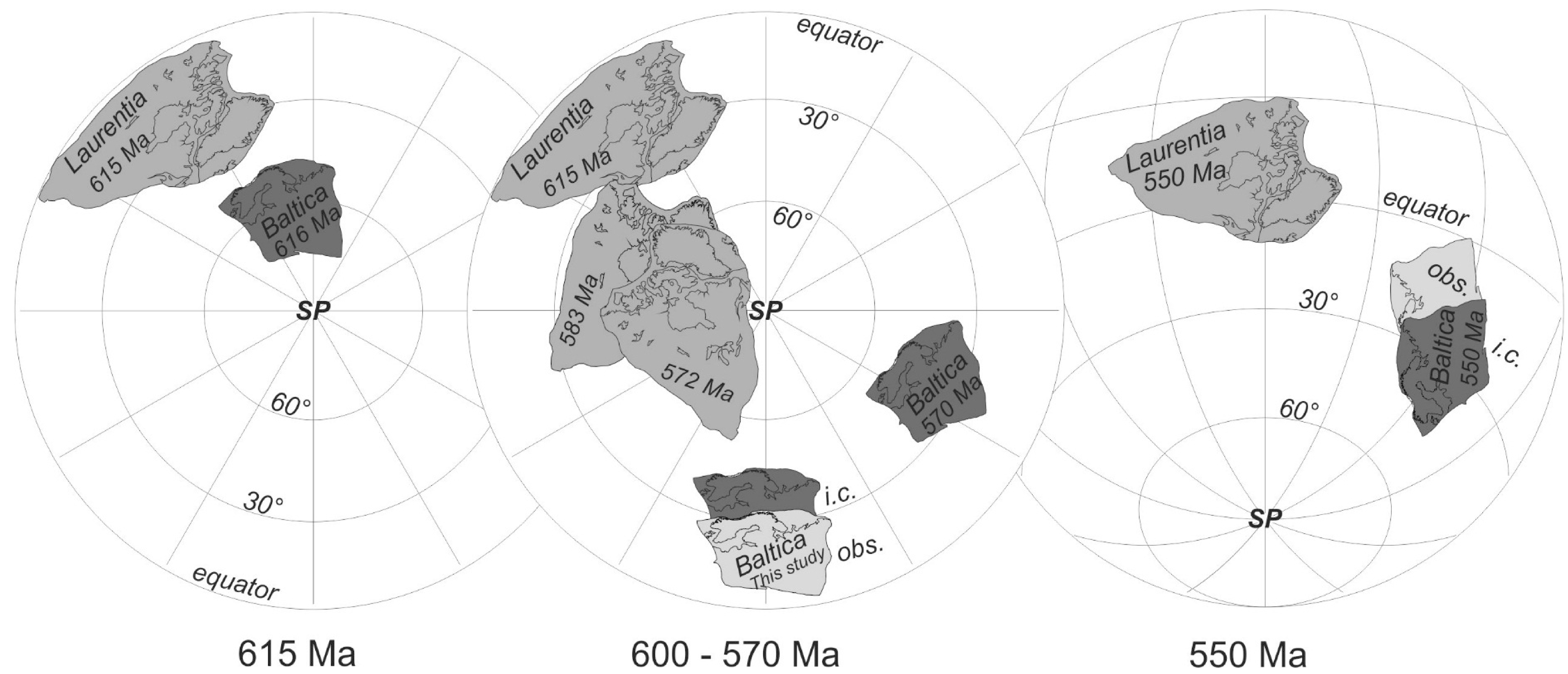

Fig. 7 